NREL National Renewable Energy Laboratory

\title{
The Terawatt Challenge for Thin-Film PV
}

Technical Report NREL/TP-520-38350

August 2005

Ken Zweibel

NREL is operated by Midwest Research Institute • Battelle

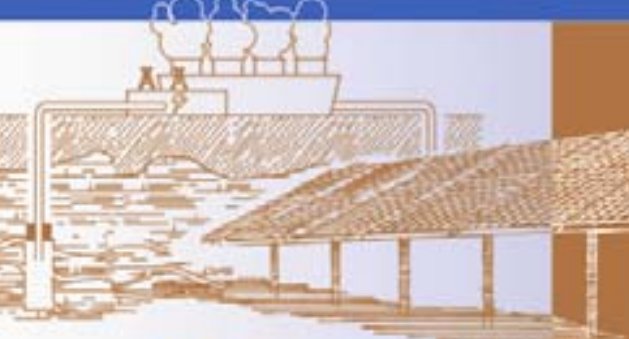

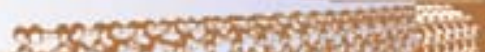
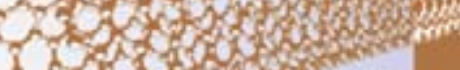

Contract No. DE-AC36-99-G010337

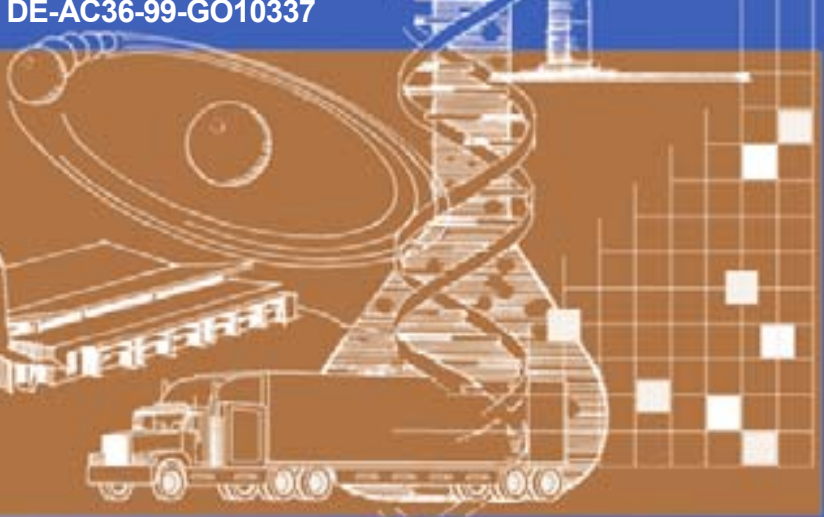




\section{The Terawatt Challenge for Thin-Film PV}

Ken Zweibel

Prepared under Task No. PVB55101

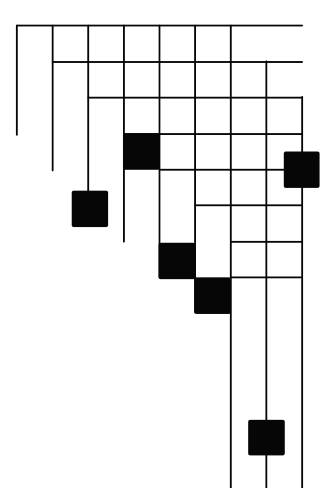

National Renewable Energy Laboratory

1617 Cole Boulevard, Golden, Colorado 80401-3393

303-275-3000 • www.nrel.gov

Operated for the U.S. Department of Energy

Office of Energy Efficiency and Renewable Energy

by Midwest Research Institute • Battelle

Contract No. DE-AC36-99-G010337 


\section{NOTICE}

This report was prepared as an account of work sponsored by an agency of the United States government. Neither the United States government nor any agency thereof, nor any of their employees, makes any warranty, express or implied, or assumes any legal liability or responsibility for the accuracy, completeness, or usefulness of any information, apparatus, product, or process disclosed, or represents that its use would not infringe privately owned rights. Reference herein to any specific commercial product, process, or service by trade name, trademark, manufacturer, or otherwise does not necessarily constitute or imply its endorsement, recommendation, or favoring by the United States government or any agency thereof. The views and opinions of authors expressed herein do not necessarily state or reflect those of the United States government or any agency thereof.

Available electronically at http://www.osti.gov/bridge

Available for a processing fee to U.S. Department of Energy and its contractors, in paper, from:

U.S. Department of Energy

Office of Scientific and Technical Information

P.O. Box 62

Oak Ridge, TN 37831-0062

phone: 865.576 .8401

fax: 865.576 .5728

email: mailto:reports@adonis.osti.gov

Available for sale to the public, in paper, from:

U.S. Department of Commerce

National Technical Information Service

5285 Port Royal Road

Springfield, VA 22161

phone: 800.553.6847

fax: 703.605.6900

email: orders@ntis.fedworld.gov

online ordering: http://www.ntis.gov/ordering.htm 


\section{TABLE OF CONTENTS}

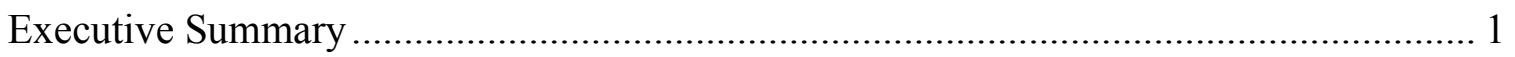

1.0 "The only big number out there - 125,000 TW" (quote, Nate Lewis, 2004) ............... 3

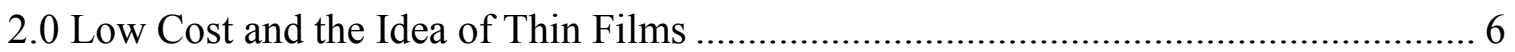

3.0 A Bottom-up Analysis of Thin Film Module Costs ................................................... 6

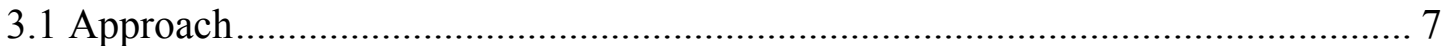

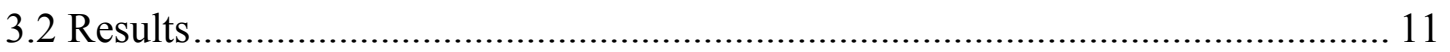

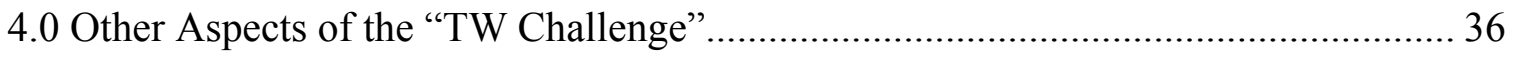

5.0 Risks and Perspective ………………................................................................. 39

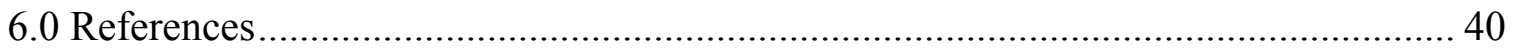

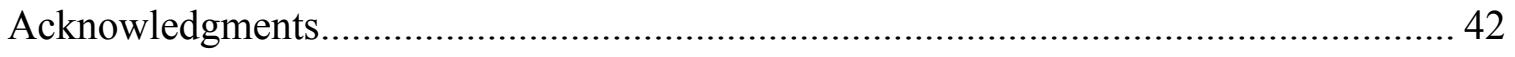

Appendix 1. Calculating Levelized Energy Cost from System \$/Wp DC Costs.............. 43

Appendix 2. Latest (prepublication) table of thin film module efficiencies taken from

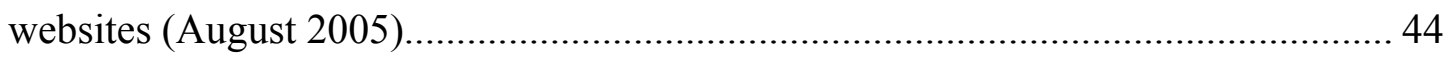




\section{The Terawatt Challenge for Thin-Film PV}

Ken Zweibel

NREL

1617 Cole Boulevard

MS 3212

Golden, CO 80401

303-384-6441

\section{Ken_zweibel@nrel.gov}

\section{Executive Summary}

It is critical to understand what this report purports to do and what it cannot do. It cannot analyze either company- or technology-specific information about thin film manufacturing. It cannot give any current actual prices, because they depend on volume and varying specifications. Thin film PV manufacturing is changing quickly, and most crucial details are confidential.

So what can this report do? It can assemble in one place a set of technology options, process choices, and device designs and attempt to give a rough estimate of their status and potential. There are long lists of these attributes that seem to indicate actual costs. But this is not the case. The lists are long to assure that as much as practical is included missing process steps or major materials components would be a serious shortfall. But the actual costs estimated under each category are simply educated guesses. With time, they will change. This is a snapshot of what the author believes is a fair picture of the landscape of thin film PV. One cannot do more; it is really rather a question of whether one should simply do less, and not publish at all. But in the interest of addressing a bigger question - "Can thin film PV meet the Terawatt Challenge?" - it seems worthwhile to make the effort, especially considering the critical importance of solar (covered in the next section) in terms of climate change and oil depletion. Solar is "the only big number out there" (in the sense of the size of the resource available to meet climate change without carbon dioxide emissions) and this matters. This report should suffice to give a sense of the progress in thin films; their potential; and what remain as major challenges.

Tables 16-19 summarize the results of the rough, but methodologically consistent cost estimates. They show that a number of thin film module options have system price potentials in the range of $\$ 1-\$ 1.2 / \mathrm{Wp}$ DC. This translates (in an average US solar location like Kansas City) to about 5-7 $\varnothing / \mathrm{kWh}$ AC electricity. Such electricity should be inexpensive enough to: (1) provide intermittent, daytime electricity from grid-tied systems and (2) split water and make hydrogen for portable fuels. If PV is to be used for dispatchable electricity, other aspects of system design and cost must be addressed through long-distance transmission and storage.

This study was conservative. There are a number of clear avenues for further PV cost reduction (e.g., through less expensive encapsulation) that could take PV prices substantially lower. 
In addition to the cost estimates, other topics associated with the "TW Challenge" include materials availability, land area needs, and energy payback. These were examined as well. In some cases there may be materials availability issues (e.g., indium and tellurium supply), while in others only the prospect of steady growth (e.g., glass). Due to the diversity of PV module options, no supply issue is critical. Land issues turn out to be a red herring - land use is actually a strength of PV since: PV can be used on roofs and other structures, it is the most efficient means of converting primary solar energy to usable form, sunlight is ubiquitously available in sufficient quantities, and only tiny amounts of land (on a relative basis) are in question (about $1 \%$ of land area). Energy payback is also found to be a non-issue, as it falls toward about 1-2 years today, and below that with further technical progress.

The evolution of PV into one of the world's largest industries is not going to happen without major unforeseen problems. However, this study attempts to address the obvious ones, so that we can put aside the mythology of PV (for example, that it is only 'boutique power' or that one must pave the world with it to be useful) and get on with changing the world's energy infrastructure. With the years of rapid market growth now underway in $\mathrm{PV}$, the author is sure this will not be the last effort to understand the real potential and pitfalls of meeting the TW Challenge. 


\section{0 "The only big number out there $-125,000$ TW" (quote, Nate Lewis, 2004)}

The world uses about 10 terawatt (TW) of energy (the US, about 3 TW) and by 2050 is projected to need about $30 \mathrm{TW}$. Thus the world will need about $20 \mathrm{TW}$ of non- $\mathrm{CO}_{2}$ energy to stabilize $\mathrm{CO}_{2}$ in the atmosphere by mid-century. For details about non- $\mathrm{CO}_{2}$ energy needs for meeting climate change, see Hoffert et al., 1998. Hoffert (NYU), Rick Smalley (Rice Nobel Laureate), and Nate Lewis (CalTech) call this the "Terawatt (TW) Challenge," and whether thin film PV can meet the challenge is the subject of this study. Shockingly, it turns out that among the non- $\mathrm{CO}_{2}$ options, it is possible that solar is the only one that can (discussed below).

The primary barrier to TW-scale use of PV is cost, and that will be the main focus of this study. Secondary barriers, including feedstock availability, land use, and energy payback, will also be covered. A final barrier, only touched on here, is system-related: How do we use intermittent PV electricity to provide dispatchable electricity and fuel? This is described in outline, but deserves a separate in-depth study.

But why is it crucial that PV be able to meet the TW Challenge? Why not other sources of non- $\mathrm{CO}_{2}$ energy? This is an important question that most policy-makers do not yet agree on, and the public is another step removed from such a consensus.

In recent presentations and publications, CalTech's Nate Lewis (2004) has emphasized that among the renewables, only solar has a large enough resource base to meet a major fraction of the world's energy needs. The rest of the renewables (wind, biomass, geothermal, hydro) do not have adequate global resources to do so - although they can meet a fraction of a TW each (still a very significant contribution, when one realizes that the US now uses 3 TW). But this means that solar (with about 125,000 TW of global incident sunlight) has both a huge opportunity and a huge responsibility.

To state clearly: Any technology that can produce at least a TW of annual energy should be considered having met the TW Challenge and contribute to the reduction of climate change. But we go further here; we want to know how many TWs thin film PV could provide by mid-century.

Key scenarios for stabilizing $\mathrm{CO}_{2}$ in the atmosphere during the $21^{\text {st }}$ century turn on the viability of $\mathrm{CO}_{2}$ sequestration. Sequestration is capturing $\mathrm{CO}_{2}$ during, e.g., coal burning, piping it to a storage location, and then pumping it into special underground storage, e.g., aquifers, where it would presumably stay without leakage for millennia. This approach is unproven but important. Much work is being done to demonstrate it.

If sequestration does not work, it is almost certain that the world will need at least $10 \mathrm{TW}$ of non- $\mathrm{CO}_{2}$ producing energy by mid-century, and perhaps as much as $20 \mathrm{TW}$, to stabilize $\mathrm{CO}_{2}$ in the atmosphere. Even nuclear power would have difficulty meeting this without breeder reactors, due to the lack of uranium fuel for present designs. But this means that nuclear has multiple problems: proliferation of breeder reactors with plutonium fuel (with concomitant global tensions and terror issues), waste disposal, and accidents. Let us put aside nuclear as possibly too dangerous. Then the simplest scenario to stabilize $\mathrm{CO}_{2}$ by mid-century is one in which PV and other renewables are used for 
electricity (10 TW) and to make hydrogen for transportation (10 TW); and fossil fuels (coal, natural gas, oil) are used to make residential and industrial heat (10 TW).

Departures from this strategy include using coal to make gasoline; but this would mean more $\mathrm{CO}_{2}$. The challenges facing solar are (1) economic (Can renewables be cheap enough? Can storage of hydrogen on vehicles be cheap enough?) and (2) infrastructure (we pump gasoline, not hydrogen; we use gasoline engines, not fuel cells or turbines). Under this scenario, and given the vastness of the solar resource, there could be a huge 10-20 TW demand for PV by mid-century. (Recall that we only use about $10 \mathrm{TW}$ worldwide today, so this is a huge amount of energy.)

But what if sequestration works? Would the need for solar be eliminated or much reduced? Perhaps not as much as one might think. Why? Let us look a little more closely at the coal/sequestration approach.

People are excited about the potential of sequestration, because if it works, coal could be used to meet most electricity demand. Everyone knows there's plenty of cheap coal. The cost of sequestration and rising demand might add about $50 \%-150 \%$ to the price of coalgenerated electricity, but it wouldn't make coal use untenable. Still, even under this scenario, some renewables would be used simply because they would be cost-competitive at these higher prices.

What about transportation?

Princeton's Bob Williams has presented a unique scenario based on biomass $\mathrm{CO}_{2}$ sequestration in which coal and biomass could be used for liquid fuels and still stabilize $\mathrm{CO}_{2}$ in the atmosphere. How? Biomass-produced $\mathrm{CO}_{2}$ sequestration could be adopted to actually remove significant $\mathrm{CO}_{2}$ from the atmosphere. This is even better than biomass being $\mathrm{CO}_{2}$ neutral; it provides a sink that can be played off against fossil fuels. Biomass used as energy or used as feedstock along with coal could make liquid fuels (e.g., gasoline). By effectively removing some $\mathrm{CO}_{2}$ from the atmosphere via the biomass, the net $\mathrm{CO}_{2}$ produced in the transportation sector (where $\mathrm{CO}_{2}$ cannot be captured) would be low enough to allow $\mathrm{CO}_{2}$ stabilization despite using a lot more coal.

Under the coal and biomass $\mathrm{CO}_{2}$ sequestration scenario, no other renewables would appear to be needed for a major fraction of the world's energy, at least until mid-century (when biomass resources would become inadequate to the task).

But this is not the last word on this key question.

Williams and Lewis have proposed an innovative idea for using solar energy to make carbon fuels, i.e., as an alternative to biomass in the sequestration scenario. If successful, such an approach would significantly increase the demand for PV despite sequestration's success.

How could PV produce carbon fuels? Lewis suggests an in-situ, electrochemical approach mimicking photosynthesis. An electrochemical solar cell would be used to combine $\mathrm{CO}_{2}$ taken from the air with hydrogen from water-splitting, producing a hydrocarbon liquid fuel. His suggested in situ approach, similar to but more complex than existing efforts to split water electrochemically with in situ PV, would require long-term research and one or more major breakthroughs. 
Perhaps we could afford the wait. Under Williams' plan for biomass sequestration, analysis suggests that biomass resources would become inadequate about mid-century. Thus development of in-situ PV synthesis of carbon fuels could take until then and still play a major role.

However, there may be simpler and shorter-term ways to harness $P V$ to remove some $\mathrm{CO}_{2}$ from the atmosphere and make hydrocarbons. Just as there is a way to use any PV electricity to split water using an (ex situ) electrolyzer, there may be ways to simply use flat-plate PV electricity to make carbon fuels. How? Carbon dioxide may be absorbed from the atmosphere (as it is by leaves in photosynthesis) or taken from the emissions of coal plants, and hydrogen from water can be combined with it to make hydrocarbons. Because concentrating atmospheric $\mathrm{CO}_{2}$ takes too much energy, the large area of a leaf or of flat-plate PV can be used to capture $\mathrm{CO}_{2}$ from the air economically. Physical and chemical processes would have to be developed to capture the $\mathrm{CO}_{2}$. But the rest of the processes are already being done: splitting the water with an electrolyzer; chemically synthesizing the hydrocarbon fuel from the $\mathrm{CO}_{2}$ and the resulting hydrogen (e.g., running a methanol fuel cell backwards), and the DC PV energy. On the PV side, the challenge is purely economic: Can PV be inexpensive enough? But it would not have to be directly competitive with gasoline prices; it would compete (under the sequestration scenario) with biomass, instead.

Thus even under the sequestration scenario, many TW of PV might be of value. Of course, without sequestration (which seems more probable), solar would be essential. And under either scenario, sequestration or not, we should establish that PV can meet the TW Challenge from an economic and materials availability standpoint.

It may be that developing PV to produce hydrocarbons (instead of hydrogen) will be important for transportation, even if sequestration fails. The cost of using PV to make a liquid fuel instead of hydrogen is approximately only the added cost of the $\mathrm{CO}_{2}$ processing, since splitting water is part of both approaches. But some of this added cost would be offset by the ease with which liquid fuels can be transported and stored (versus hydrogen) and the presence of the whole liquid fuel infrastructure in transportation. Then there would be further cost savings during use in vehicles, as the weight advantage of liquid fuels is significant. In fact, many policy makers are skeptical about whether the use of hydrogen for transportation is feasible at all, due to these factors. One way or another, $\mathrm{PV}$ as the source of non-CO $\mathrm{C}_{2}$ energy for making hydrocarbons or hydrogen could play a critical role in the transportation sector.

There is another collateral value to making hydrogen or hydrocarbons - storage. PV is intermittent. Measures must be taken to smooth the delivery of solar energy to meet fluctuating demand, especially at night, during cloudy periods, or for seasonal extremes. Two methods of doing this exist: storage and long-distance transmission. Storage could be accomplished by making hydrogen or hydrocarbons for conversion back to electricity. Other supply and demand mismatches could be minimized by improving long-distance transmission. National and supra-national grids could be upgraded to support large proportions of intermittent PV and wind; and to best use fossil fuels, storage, and other renewables. And multi-continent (even multi-hemispheric) transmission (e.g., Colbert and Smalley, 2002) could also fill gaps. Some of these infrastructure adjustments will be necessary to bring on the solar age. 
As always, the bottom line is PV cost. Solar can meet energy needs globally from a resource standpoint. What would it have to cost to do it cost-effectively? Each market has a different system cost and competitive price. And competitive prices will change with time, especially in a carbon-constrained world, or if oil becomes more expensive. This study will establish that thin film PV costs can be brought down to about $5 \mathrm{c} / \mathrm{kWh}$. (There are pathways that would take these costs even lower, but they are more speculative.) $5 \phi / \mathrm{kWh}$ seems adequate to provide energy (electricity and transportation fuel) at prices not-too-different from today's prices.

The need for solar by mid-century could be 10-20 TW. "Solar is the only big number out there," as Lewis would say. We have to find ways to use that resource. Thus it is incumbent on the PV community to re-think how it can meet the challenge, including facing issues such as reaching ultra low costs; managing explosive growth (with any materials bottlenecks that might occur); and producing, deploying, and using PV systems on an unheard of scale.

There may be other ways to make low-cost PV than thin films (e.g., wafer silicon or concentrating PV), but thin films are paradigmatically designed for low cost; and they are the focus of this study.

\subsection{Low Cost and the Idea of Thin Films}

The idea of thin films is simple: use mostly low cost material (glass, metal, plastic) and very little high-cost semiconductor. A micron or so of semiconductor is about $2-6 \mathrm{~g} / \mathrm{m}^{2}$; even ultra-expensive material (say, $\$ 1000 / \mathrm{kg}$ ) only costs pennies per watt at this level. This idea has been around as long as PV, but the difficulty has been developing semiconductors that would work well enough (have high enough conversion efficiency) and then finding ways to actually make them cheaply at high yield. And thin films have their own peculiar stability issues, both intrinsically and at the module level, which have also added to the challenge. However, throughout, the idea of thin films has maintained its power, so that no single failure or long, costly delay has destroyed thin film development. But setbacks have taught us something about what is needed. Fortunately, thin films today are approaching technical readiness (Zweibel et al., 2004), achieving measurable and growing market share, and may finally show that they have an excellent chance of reaching truly low cost. This study makes an attempt to explain why thin films are likely to be successful for meeting large-scale PV electricity demands.

\subsection{A Bottom-up Analysis of Thin Film Module Costs}

Almost all thin film PV devices have a great deal in common. They attempt to minimize material costs by using ultra-thin semiconductors to convert sunlight to electricity; they attempt to reach adequate sunlight-to-electricity conversion efficiencies; and they require excellent outdoor reliability. In this sense, thin films are a direct response to the high materials costs of wafer silicon PV modules.

However, thin film modules share most functional aspects with wafer silicon modules. That is, they require top and bottom protection from the outdoor environment, so that 
they can last outdoors about thirty years. They need top and bottom contacts, bus bars, and a connection to an external circuit to carry away current. They need ways to connect the cells together to provide the right balance of voltage and current. They need some sort of mounting scheme, or at least the ability to be mounted if none is explicitly included. They may need edge seals and edge protection, such as an edge delete. All in all, there is a great deal that thin film modules have in common with crystalline silicon modules; and with each other, no matter what the semiconductor converter is. These commonalities can be called the balance of module, or BOM. Importantly, they turn out to be a significant portion of module cost. (See tables below for particulars.)

The presence of substantial BOM means that (1) reaching the highest possible efficiencies and (2) reducing the manufacturing costs of the active elements of thin film modules are essential if they are to be competitive in the PV marketplace - not to mention (the real goal of all PV development), to be able to be competitive with fossil fuels. Cost reductions must come from reducing semiconductor materials costs, energy costs, capital costs, maintenance costs; and intending to use the largest substrate areas possible with easily connected cells to allow for the fullest automation. This must all be done while also optimizing conversion efficiencies, yield, and stability.

This simple comparison with crystalline silicon sets the stage for what follows (a comparison among thin films in greater depth) and is a caution against the idea that all thin films are automatically cheaper at the system level than wafer X-Si technologies. Such a system cost advantage can be tenuous or absent, and only a full exploitation of the potential advantages of thin films in real designs can lead to success in the marketplace; and more importantly, to a cost low enough to meet climate change and fossil fuel depletion needs on a global scale. Fortunately, several thin films (CdTe and a-Si products) are already competitive in the marketplace, so many challenges have been overcome.

Thin films share enough costs in common (BOM from encapsulation, contacting, and other shared costs; balance of system costs extrinsic to them) that efficiency is a very important parameter for defraying these shared costs (Von Roedern et al. 2005).

\subsection{Approach}

A spreadsheet was developed for the estimated component costs of thin film modules of various types. This was done in two parts - so-called commonalities or BOM of most thin film modules; and the unique aspects of each design, being mostly the semiconductors that convert sunlight to electricity (non-BOM). An initial production level of $25 \mathrm{MWp} / \mathrm{yr}$ was assumed, which is like the capacity of existing facilities or those that are planned b y new start-ups. Then similar estimates were developed for future, larger-scale production levels, in which both economies of scale and technical progress were estimated.

In most cases, thin film manufacturing bifurcates into: (1) approaches that take advantage of high-quality processes that cost more but produce the best films; or (2) less-expensive processes that produce less-efficient devices. Another bifurcation is between glass and flexible substrates, and this can have implications at the system cost level (discussed below). In addition, some technologies have low semiconductor materials costs almost independent of how wasteful the approach; others are very sensitive to materials 
utilization rates. List 1 shows the primary set of thin film approaches examined here and the breakdown along these lines, with some simplifications where possible. We do not know which of these various strategies will be the best. Nor will any of them with only current technology meet the TW Challenge - significant R\&D still needs to be done. But many of them have the potential if fully developed.

\section{List 1. Characteristic thin film designs}

\begin{tabular}{|l|l|}
\hline Technology & $\begin{array}{l}\text { Selected example } \\
\text { companies }\end{array}$ \\
\hline $\begin{array}{l}\text { Batch amorphous silicon on } \\
\text { glass }\end{array}$ & EPV \\
\hline $\begin{array}{l}\text { In-line or clustered } \\
\text { amorphous silicon or thin } \\
\text { film-Si on glass }\end{array}$ & Mitsubishi, Kaneka, Sharp \\
\hline $\begin{array}{l}\text { In-line a-Si or thin x-Si on } \\
\text { flexible substrates }\end{array}$ & UniSolar, Iowa Thin Films \\
\hline $\begin{array}{l}\text { CdTe on glass } \\
\text { CIS/glass, good materials } \\
\text { use, moderate-high capital }\end{array}$ & $\begin{array}{l}\text { ISET } \\
\text { Solar Fields, First Solar }\end{array}$ \\
\hline $\begin{array}{l}\text { CIS/glass, poor materials } \\
\text { use, moderate-high capital }\end{array}$ & $\begin{array}{l}\text { Wurth, Shell Solar, Showa } \\
\text { Shell, Honda }\end{array}$ \\
\hline $\begin{array}{l}\text { CIS/glass, good materials } \\
\text { use, low capital }\end{array}$ & \\
\hline $\begin{array}{l}\text { CIS/glass, poor materials } \\
\text { use, low capital }\end{array}$ & $\begin{array}{l}\text { CIS/flexible, good materials } \\
\text { use, moderate-high capital }\end{array}$ \\
\hline $\begin{array}{l}\text { CIS/flexible, poor materials } \\
\text { use, moderate-high capital } \\
\text { use, low capital }\end{array}$ & Global Solar \\
\hline $\begin{array}{l}\text { CIS/flexible, good materials } \\
\text { Useveral startups: e.g., } \\
\text { Miasole, Daystar, } \\
\text { Nanosolar }\end{array}$ \\
\hline
\end{tabular}

The technologies will be analyzed in these broad categories to capture the impacts of each difference in cost and efficiency. In no cases are actual company costs used, since these are not known and could not be used if they were. In addition, by retaining some flexibility, more present and future variations could be examined rather than being 
limited to actual process lines and device designs. It will be established that this approach does not much affect the accuracy or ruggedness of the estimates. In fact, in all cases, there is substantial overlap that underpins comparisons, e.g., efficiency, substrates, and BOM. The differences can be smaller than the similarities.

In addition to the above, some newer thin film technologies were also investigated, but in a more rudimentary fashion. These technologies are 5-20 years behind developmentally those in Table 1, and the purpose of examining them is to see if they have potential to be even better if all research challenges are overcome. However, meeting the TW Challenge does not require that any technologies beyond those given in Table 1 (and existing $\mathrm{x}-\mathrm{Si}$ ) be developed (but no doubt, some will be, reducing risks even further).

Various sources were used for these estimates. The most critical challenge was to get the right process steps and the right set of materials. If process steps or materials are missing, then the analysis can be off substantially. Literature, presentations, parallel work at NREL, and private communications were the source of the process steps. However, it is almost certain that a few, idiosyncratic processes were missed, as these are the least likely to be publicly discussed. Shunt curing and photolithography are examples of processes that may be overlooked (but actually, were not). Steps like these are not major costs, and they vary among approaches. To capture this type of missing information, a small additional "miscellaneous" category was included for all options.

There is a further check on near-term cost analysis: Both the amorphous silicon and CdTe technologies are in production at the $25 \mathrm{MWp} / \mathrm{yr}$ level, and several companies publicly announced that they are profitable (e.g., First Solar and UniSolar, May 2005). Thus one can deduce that their costs are within a reasonable range of those of $\mathrm{x}$-Si for existing production. Similarly, many companies publish partial accounting of their costs (e.g., total capital investment for new plants). Both First Solar and UniSolar did this recently ( $\$ 2.5 / \mathrm{Wp}$ for UniSolar and $\$ 1.2 / \mathrm{Wp}$ for First Solar, from press releases). Others have as well. Another example of an 'easy' cost to estimate is semiconductor materials. The feedstock costs can be found (e.g., Appendix 1 of Keshner and Arya 2004) and the layer thicknesses estimated from published articles on cells. The fraction of material wasted is important, since this can vary greatly. All in all, many aspects of production can be estimated in a like manner.

Estimates included processing equipment and the materials, and other associated costs such as labor, energy, and rent. The BOM costs were easiest, since they are usually commodity materials such as glass, metal, plastic, or EVA. In those cases, quotes were taken from the internet, from vendors, or from private communications. In many cases, common sense estimates were made based on these inputs. No number represents an absolute, since vendors vary, prices vary with volume, and costs change. They are educated estimates, and that's all they should be viewed as. Where they are cost-drivers, care was taken to assure that they are reasonable.

The non-BOM portion was more challenging, but estimates are possible from publications; and trends are relatively easy to discern. Handling and other miscellany were included. Maintenance was taken as $4 \%$ of the initial capital cost for all technologies. Capital cost per unit output was assumed to be based on a capital recovery factor of $15 \%$ per year. 
Analysis was also done of future costs, based on expected technical progress. For example, costs can be adjusted for thinner layers and improved process waste percentages. Based on an increase in throughput (from faster film fabrication, from thinner layers, and wider substrates, etc.), capital, maintenance, energy, rent and other costs can be adjusted. This type of analysis was done to project future cost trajectories.

In several cases the author received private communications of in-depth breakdowns of entire thin film processes from private sector sources. But these were always given within a framework of confidentiality, to be used in a generic, non-attributable way. That is why they cannot be referenced; and the particulars of processes are not broken down in parallel to any single company's approach. Yet detailed numbers exist that back up the results given here, and often the author's estimates agree quite closely or are higher than numbers mentioned in various venues (conferences, workshops, group conversations).

In all cases, some common sense had to be used. No single cost number is usable alone; experience and insight must be applied. A synthesis was made.

Are the estimates off? Definitely, but likely within reason. Are the process sequences off? Probably not much, except for the proprietary aspects. It is the author's belief that the estimates in this chapter for Table 1 thin films will track real world costs within about $20 \%$. For others (so-called $3 \mathrm{G}$ thin films), the uncertainty is much greater and will be noted where possible.

A simple, but important arithmetic relationship underlies the analysis. Most PV costs are given in dollars per watt peak $(\$ / \mathrm{Wp})$. This is fine for the end user (especially if it is a system price), but it hides the nature of the technical challenges, especially in thin films. Two components go into a cost in $\$ / \mathrm{Wp}$ : the output or efficiency of the device; and its manufacturing cost per unit area. By combining them you get a cost in $\$ / \mathrm{Wp}$. However, costs and efficiency vary greatly among thin films. There are many thin film options with very low potential costs (especially, potentially low non-BOM costs), but often they have inadequate efficiencies, resulting in high $\$ / \mathrm{Wp}$ costs. Their challenge is to raise their performance. But this is often overlooked when people merely highlight their low nonBOM manufacturing cost. Conversely, there might be thin films with high efficiency that have high area costs, and the balance determines their competitiveness.

The actual relationship is very simple: the dollars per watt cost can be found simply by dividing the manufacturing costs per unit area (say $\$ / \mathrm{m}^{2}$ ) by the output of the same area (which for $\mathrm{a} \mathrm{m}^{2}$ is $1000 \mathrm{Wp} / \mathrm{m}^{2}$ times the efficiency). The same relationship works at the module level: the module cost (in \$/module) divided by its output (Wp/module) is its \$/Wp cost. Obviously, the same relationships show how to go the other way: if one knows the $\$ / \mathrm{Wp}$ cost and either the efficiency (or unit output) or the area cost, one can calculate the missing parameter. The simple relationship is as follows:

$$
\$ / \mathrm{Wp}=(\text { Cost/unit area) } / \text { (output/unit area). }
$$

Unit area can be the module area; or, as in this chapter, the cost per square meter. Output per square meter is $1000 \mathrm{Wp} / \mathrm{m}^{2}$ times the efficiency (or it is the module's nameplate rating at STC). Thus a $\$ 10 / \mathrm{m}^{2}$ area cost for a $10 \%$ module is $\$ 0.1 / \mathrm{Wp}$; and for a $5 \%$ module, it is $\$ 0.2 / \mathrm{Wp}$. A $\$ 1 / \mathrm{Wp}$ cost for an $8 \%$ module implies an $\$ 80 / \mathrm{m}^{2}$ manufacturing area cost; but for a $12 \%$ module, it's $\$ 120 / \mathrm{m}^{2}$. This is all arithmetic using the relation 
above. Because thin film technologies vary across a wide spectrum in both cost and efficiency, this is the way the analysis must be done to reveal underlying issues.

\subsection{Results}

For the commonalities (BOM) among all thin film modules, a set of distinct substrates were chosen: glass, stainless steel, and polyimide. Only those substrates and encapsulation schemes that are already in common use were chosen (e.g., glass/EVA, Tefzel/EVA), and this could be viewed as a limitation of the study (since they are all rather expensive). However, since encapsulation is crucial for reliability, it seemed the proper choice. To first order, any cost breakthrough in encapsulation is likely to benefit all thin films (and $\mathrm{x}-\mathrm{Si}$ ), and could be treated independently. (If individual technologies have uniquely lower-cost options for encapsulation, they should try to develop and implement them as fast as possible to gain a competitive advantage over those given here. More likely, they have specific problems that require somewhat more robust encapsulation and incrementally higher cost.)

Then estimates of the rest of the functional aspects of the BOM were added to the three substrate options (see Table 1 for a detailed example with glass), except for sales, marketing, management, R\&D, warranty, shipping, taxes, and profit. (These are actually added later at the system price level.) Each BOM design had a top and bottom contact (including TCO); each had bus bars and wires out; each had adhesive where needed. All cost categories were included: materials, equipment and maintenance, labor, facilities. Where materials were the same between designs (e.g., EVA adhesive or Tefzel or transparent conductive oxides, back contact metals) the same assumptions were used throughout, but adjusted if there were differences of thickness or processes. Cell interconnection monolithically or by soldering was also included.

Note that this means that the only aspects of the design that will vary for the non-BOM portion of the thin film device will be between the two contacts (where those contacts include the top TCO and the bottom metal). This approach makes the analysis quite generic, but it does sacrifice some aspects of specificity.

Table 1 shows the estimated breakdown of BOM commonalities for the simplest of all thin film designs: a glass-to-glass superstrate with tin oxide transparent conductive oxide (TCO) on top; and EVA adhesive and glass on the bottom. The $2^{\text {nd }}$ case, last column of Table 1 is where a substrate glass is used and the TCO is added before the top piece of glass is added. (The slightly higher cost for this $2^{\text {nd }}$ case reflects the volume advantage of buying glass/TCO from a glassmaker instead of making it in small volumes.) It should be emphasized that all numbers in this chapter are estimates and will likely change over time due to design changes, volume purchases, or innovations. Some of that is built into later Tables. 
Table 1. Estimated BOM commonalities of glass/TCO/glass module designs; direct manufacturing cost @25 MWp/yr ${ }^{1,2}$

\begin{tabular}{|c|c|c|c|c|}
\hline Unit & Component & $\begin{array}{l}\text { Detail } \\
\text { CVD or }\end{array}$ & $\begin{array}{l}\text { Buy } \\
\text { glass } \\
\text { w/TCO }\end{array}$ & $\begin{array}{l}\text { Substrate } \\
\text { glass } \\
\text { Version) }\end{array}$ \\
\hline$\$ / \mathrm{m}^{2}$ & Front contact or TCO capital cost & sputtering & $\mathrm{N} / \mathrm{a}$ & 2 \\
\hline$\$ / m^{2}$ & Laminator & & 2 & 2 \\
\hline$\$ / \mathrm{m}^{2}$ & Scriber/cell interconnection & scriber & 2 & 2 \\
\hline$\$ / \mathrm{m}^{2}$ & Back contact capital cost & $\begin{array}{l}\text { sputtering } \\
\text { sodalime }\end{array}$ & 2 & 2 \\
\hline$\$ / \mathrm{m}^{2}$ & Substrate and preparation & glass & 10 & 7 \\
\hline$\$ / m^{2}$ & Front contact materials & target or gas & $\mathrm{N} / \mathrm{a}$ & 5 \\
\hline$\$ / \mathrm{m}^{2}$ & Back contact materials & target & 0.6 & 0.5 \\
\hline$\$ / m^{2}$ & Maintenance & & 2 & 2.7 \\
\hline$\$ / \mathrm{m}^{2}$ & Misc handling costs & glass & 1.5 & 1.5 \\
\hline$\$ / m^{2}$ & Packaging and shipping & & 1.5 & 1.5 \\
\hline$\$ / \mathrm{m}^{2}$ & Adhesive & $\begin{array}{l}\text { EVA } \\
\text { sodalime }\end{array}$ & 3.7 & 3.7 \\
\hline$\$ / \mathrm{m}^{2}$ & Encapsulating layer and prep & glass & 7 & 7 \\
\hline$\$ / \mathrm{m}^{2}$ equivalent & Bus bars & & 2 & 2 \\
\hline$\$ / \mathrm{m}^{2}$ equivalent & Wires and 'jbox' & & 4 & 4 \\
\hline$\$ / \mathrm{m}^{2}$ equivalent & Edge seals mat and capital & & 1 & 1 \\
\hline$\$ / \mathrm{m}^{2}$ equivalent & Frame or mounting scheme & & 3 & 3 \\
\hline$\$ / \mathrm{m}^{2}$ equivalent & Specialty chemicals & & 0.5 & 0.6 \\
\hline$\$ / \mathrm{m}^{2}$ equivalent & Utilities (BOM only) & & 2 & 3 \\
\hline$\$ / \mathrm{m}^{2}$ equivalent & Rent (BOM only) & & 2 & 2 \\
\hline$\$ / \mathrm{m}^{2}$ equivalent & Labor (BOM only) & & 5 & 6 \\
\hline$\$ / \mathrm{m}^{2}$ & Subtotal & & 51 & 58 \\
\hline$\%$ & Yield on BOM & & 0.95 & 0.95 \\
\hline $\begin{array}{l}\$ / \mathrm{m}^{2} \\
{ }^{1} \text { For perspective: if a } \\
\mathrm{MW}, \$ 1 / \mathrm{m}^{2} \text { is equival } \\
\text { (about } \$ 60 / \mathrm{m}^{2} \text { ) woul } \\
\text { efficiency, the BOM }\end{array}$ & $\begin{array}{l}\text { Total of BOM commonalities } \\
\text { dule is } 10 \% \text { efficient }\left(100 \mathrm{~W} / \mathrm{m}^{2}\right), \$ 1 / \mathrm{m}^{2} \text { is } \\
\text { to } \$ 250,000 \text { of annual costs }(\text { about } 2 \% \text { of } \\
\text { en be equivalent to about } \$ 15 \mathrm{M} / \mathrm{yr} \text {, or } \$ 0.6 \\
\text { tself would be } \$ 1 / \mathrm{Wp} \text {. }\end{array}$ & $\begin{array}{l}1 / \mathrm{Wp} \text {; and if ann } \\
\text { BOM costs). The } \\
\text { However, at } 5 \%\end{array}$ & $\begin{array}{l}\mathbf{5 4} \\
\text { al output } \\
\text { total BON } \\
\text { module }\end{array}$ & $\begin{array}{r}62 \\
\text { s } 25\end{array}$ \\
\hline
\end{tabular}

But the classic glass-to-glass module is not the only possible encapsulation design. Tables 2 and 3 provide a summary of the entire spectrum of BOM combinations at current cost and production levels. As such, they provide a lower-cost "floor" for almost all thin films today (since each thin film has one of these BOM); and that floor tends to be in the $\$ 60-\$ 75 / \mathrm{m}^{2}$ range, without a single active conversion element being added to the design. This is an important result, since, for example, the long-term DOE goal for thin film modules is under $\$ 50 / \mathrm{m}^{2}$, including all aspects. However, recall that these BOM estimates are a snapshot of current costs. They do not include any improved designs or 
economies of scale. These can be expected to be significant. In fact, one may expect BOM costs to drop by about $25 \%-50 \%$ in some future, steady-state, high volume scenario, without significant design changes (see Table 5, and discussion below). With design changes (such as replacing the back encapsulation with a thin film barrier layer, or with other radical changes that somehow maintain reliability), the reduction could be even greater. However, a stubborn BOM debit of about $\$ 20-\$ 40 / \mathrm{m}^{2}$ (perhaps less with design changes), even in the future, is important to include in planning for thin film research. It tends to keep efficiency high on the research priority list.

Table 2. Summary of estimated BOM commonalities at $25 \mathrm{MWp} / \mathrm{yr}$ level, near-term

\begin{tabular}{|l|l|l|}
\hline $\begin{array}{l}\text { Glass/TCO/EVA/glass } \\
\text { or } \\
\text { Glass/EVA/metal/glass }\end{array}$ & $\begin{array}{l}\text { Tefzel/EVA/stainless } \\
\text { steel/EVA/tefzel }\end{array}$ & Tefzel/EVA/polyimide/EVA/tefzel \\
\hline $54-62 \$ / \mathrm{m}^{2}$ & $67-79 \$ / \mathrm{m}^{2}$ & $70 \$ / \mathrm{m}^{2}$ \\
\hline
\end{tabular}

A few observations about Table 2:

- The use of stainless steel or polyimide today engenders the need for a second, bottom encapsulation barrier, in this case EVA/Tefzel (or EVA/glass), which adds significant expense (for comparison, glass does double duty as a substrate and encapsulant).

- However, flexible modules laminated on roofs have significant BOS advantages for that application, which can more than offset this extra module cost. This will be discussed later.

- Future designs to use less-expensive substitutes for any of these materials will demand substantial reliability testing.

- However, volume production and on-site manufacturing (e.g., for EVA, Tefzel, glass) would affect these costs positively. To be conservative, these are not taken into account in this study.

BOM commonalities were also developed for nonstandard designs, e.g., for 2-junction thin films both as two- and four-terminal devices. These required different BOM choices for scribing, for contacts between the top and bottom junctions, and for external wiring. A summary is given in Table 3 .

Table 3. Summary of estimated BOM commonalities at $25 \mathrm{MWp} / \mathrm{yr}$ level, near-term, for multijunctions (all glass/EVA/glass design)

\begin{tabular}{|l|l|}
\hline Two-terminal design & Four-terminal design \\
\hline $56 \$ / \mathrm{m}^{2}$ & $73 \$ / \mathrm{m}^{2}$ \\
\hline
\end{tabular}


Observations about Table 3:

- The 2-terminal design is essentially the same as the basic glass/EVA/glass design for a single-junction (i.e., this is like some existing two-junction a-Si designs only a small debit for a tunnel junction is added to the BOM);

- The about $\$ 15 / \mathrm{m}^{2}$ added BOM cost of the four-terminal design implies about $1 \%$ in efficiency debit (depending on module efficiency) versus a single-junction or a 2-terminal BOM design, before any additional cost for the semiconductors themselves is added. Obviously, these added costs must be offset by greater efficiency to make this choice cost-effective versus the 2-terminal approach or versus a single-junction competitor.

- The payoff for multijunctions is in potentially higher efficiencies, which help offset BOM and area-related BOS costs.

To find total module cost, designs for the active semiconductor portions (non-BOM) of each thin film technology were developed, including multiple designs (such as in CIS) where warranted by different processing schemes. In other words, physical vapor deposition (PVD) approaches, chemical vapor deposition (CVD) approaches, precursors and selenization approaches - all the recognized ways that thin films such as CIS, a-Si, and CdTe are made - were estimated. However, no effort was made to exactly replicate any company's specific approach, for obvious and numerous reasons (e.g., it can't be done; and it shouldn't be done for confidentiality purposes). So in that sense, even at the most detailed level, there were some limitations on precision. However, every effort was made to make the numbers true to a current best-estimate of costs for plants of the sizes given in some steady-state (i.e., without first-time design costs). For a look at various cell and module designs and process sequences, see: e.g., R. Wieting, 2005; Basore 2004; Delahoy et al. 2004; Guha and Yang, 2003; Enzenroth et al., 2004; Powell, 2004, Jansen et al. (2005). However, this is not an all inclusive list of resources, as pointed out in the introduction.

Table 4 shows the non-BOM breakdown of one technology (superstrate batch process a$\mathrm{Si} / \mathrm{a}-\mathrm{Si}$ on TCO/glass) with the various process steps and other inputs (parallel to Table 1 for BOM). Notice that it does not include anything for either top or bottom contacts. It is just the 'difference' appropriate to this approach. 
Table 4. Estimated non-BOM (active materials) breakdown for a-Si double junction made on TCO/glass using the batch process (many substrates at once) @ $25 \mathrm{MWp} / \mathrm{yr}$

\begin{tabular}{|c|c|c|}
\hline $\begin{array}{l}\text { Non-BOM } \\
\text { only }\end{array}$ & Level 1: 1-3 years (25 MW/yr) & $\begin{array}{l}\text { Batch } \\
\text { a-Si }\end{array}$ \\
\hline$\$ / m^{2}$ & absorber capital & 6 \\
\hline$\$ / m^{2}$ & absorber material & 1.5 \\
\hline$\$ / m^{2}$ & junction partner capital & 1 \\
\hline$\$ / m^{2}$ & junction partner material & 0.1 \\
\hline$\$ / m^{2}$ & buffer capital & 0.5 \\
\hline$\$ / m^{2}$ & buffer material & 0.2 \\
\hline$\$ / m^{2}$ & back reflector & 3 \\
\hline$\$ / m^{2}$ & extra tunnel junctions & 0.5 \\
\hline$\$ / m^{2}$ & Cell testing and binning & 1 \\
\hline$\$ / m^{2}$ & coatings to protect layers & 0.2 \\
\hline$\$ / m^{2}$ & Specialty chemicals & 1 \\
\hline$\$ / m^{2}$ & misc treatments cap and materials & 1 \\
\hline$\$ / m^{2}$ & Rent & 3 \\
\hline$\$ / m^{2}$ & Labor & 4 \\
\hline$\$ / m^{2}$ & maintenance & 2 \\
\hline$\$ / m^{2}$ & utilities & 6 \\
\hline$\$ / m^{2}$ & subtotal & 31 \\
\hline$\%$ & yield on active materials & 0.85 \\
\hline$\%$ & module efficiency, total area & 6 \\
\hline$\$ / \mathbf{m}^{2}$ & Total non-BOM & $\$ 37$ \\
\hline$\$ / \mathbf{W p}$ & Total non-BOM @ 6\% module efficiency & $\$ 0.61 / \mathrm{Wp}$ \\
\hline$\$ / \mathbf{m}^{2}$ & Proper BOM for Glass/TCO/glass & $\$ 54$ \\
\hline$\$ / m 2$ & ES\&H & $\$ 3$ \\
\hline$\$ / \mathbf{m}^{2}$ & Total module & $\$ 93$ \\
\hline$\$ / \mathbf{W p}$ & Total module @ 6\% & $\$ 1.56 / \mathrm{Wp}$ \\
\hline
\end{tabular}

Table 4 shows the categories used to break down each of the technologies, as well as a sense of what cost estimates were made. The resulting $\$ 1.56 / \mathrm{Wp}$ direct manufacturing cost for a-Si/a-Si modules at $6 \%$ efficiency seems quite reasonable in comparison to sales prices (about $\$ 2.25 / \mathrm{Wp}$ in some markets) in today's low-volume, high-overhead marketplace (at production levels that are not yet at $25 \mathrm{MWp} / \mathrm{yr}$ ). At $6 \%$ module efficiency, $1 \$ / \mathrm{m}^{2}$ is $2 \notin / \mathrm{Wp}$ (@85\% yield), so (for example), non-BOM capital equipment and related maintenance contribute only 10 times this, or about $20 \notin / \mathrm{Wp}$. This is the advantage of the a-Si batch process and some other similarly low-capital cost approaches (e.g., CdTe). It also means the initial capital investment is low (subtracting maintenance): only $\$ 1.8 / \mathrm{Wp}$ of capacity (or about $\$ 45 \mathrm{M}$ for $25 \mathrm{MWp} / \mathrm{yr}$ capacity). Note that at higher efficiencies, these same dollar/square meter costs would yield much lower dollar per watt costs and initial investments. This is the flip-side for a-Si batch processing - the efficiencies are low. 
As already stated, in the case of dye-sensitized, plastic cells, and quantum dots, which are not yet in prototype production, estimates were less secure. In fact, this is a well-known problem with all cost projections: numbers that are further from being reduced to practice are fuzziest and prone to the largest mistakes and biases. In this study, some liberalism was used in estimating the costs of the non-BOM portions of these so-called thirdgeneration (3G) thin films (because such costs are considered their unique strength); but a more moderate liberalism was used in re their projected efficiencies (since this is their greatest challenge). However, they were all taken to be stable long-term. This is quite optimistic. But the choice was made for a simple reason: any major instability problem would probably make these technologies totally noncompetitive (except for unique but small niche markets). In summary: the $2 \mathrm{G}$ thin films (CIS, CdTe, a-Si) were treated rather conservatively (because they are more mature and there is more data); BOM was treated rather conservatively, with no assumptions about large economies of scale; $3 \mathrm{G}$ thin films were given the "benefit of the doubt" simply to show their potential value. Predictions for $2 \mathrm{G}$ thin films should be seen as "realistic"; predictions for $3 \mathrm{G}$ thin films as "optimistic."

To allow parametric studies of the technologies near-term and at several levels of future development and manufacturing capacity, the source spreadsheet was expanded to provide estimates of future developments in thin films.. Both BOM-commonalities and non-commonalities (non-BOM) were varied with levels of technical maturity and throughput.

In terms of BOM commonalities, an assumed cost reduction of $10 \%$ was applied at each level of increased single-plant throughput. The first level of production was assumed to be about $25 \mathrm{MWp}$; and subsequent levels were increased to 50, 200 and $1000 \mathrm{MWp} / \mathrm{yr}$, with concomitant BOM cost reductions. In the end, the final level of BOM costs was reduced by about $25 \%$ from the original value for each BOM design. This is less aggressive than an $80 \%$ learning curve would imply from these volumes, which would have led to a reduction of about $60 \%$; but BOM volume production is already being achieved through the existing $\mathrm{x}-\mathrm{Si}$ volume increases, so BOM cost reductions will likely take a more modest slope with time than non-BOM reductions in thin films.

Table 5. A summary of the possible cost evolution of BOM commonalities at different throughput/maturity levels $\left(\$ / \mathrm{m}^{2}\right)$; BOM reduced $10 \%$ at each larger production level

\begin{tabular}{|l|l|l|l|l|l|}
\hline $\begin{array}{l}\text { Annual } \\
\text { single- } \\
\text { plant } \\
\text { production }\end{array}$ & $\begin{array}{l}\text { Glass/EVA/ } \\
\text { glass }\end{array}$ & $\begin{array}{l}\text { Tefzel/EVA } \\
\text { /stainless } \\
\text { steel/EVA/ } \\
\text { Tefzel }\end{array}$ & $\begin{array}{l}\text { Tefzel/EVA/po } \\
\text { lyimide/EVA/ } \\
\text { Tefzel }\end{array}$ & $\begin{array}{l}\text { 2-terminal } \\
\text { Glass/EVA/ } / \text { /ass } \\
\text { glass }\end{array}$ & $\begin{array}{l}\text { 4-terminal } \\
\text { Glass/EVA } \\
\text { /glass }\end{array}$ \\
\hline $\begin{array}{l}\text { Soon (25 } \\
\text { MWp) }\end{array}$ & 54 & 67 & 70 & 56 & 73 \\
\hline 50 MWp & 49 & 60 & 63 & 50 & 66 \\
\hline $\mathbf{2 0 0 ~ M W p ~}$ & 44 & 54 & 57 & 45 & 59 \\
\hline GWp & 39 & 49 & 51 & 41 & 53 \\
\hline
\end{tabular}


In a recent study (Keshner and Arya, 2004), a bottom-up approach was taken with BOM, showing that volume purchases and make-buy decisions could contribute substantially to cost reductions; as could design alternatives. Their glass/TCO BOM costs were $50 \%$ lower than those assumed here for the long term (about $\$ 10-20 / \mathrm{m}^{2}$ ). Part of the reason was more-aggressive design assumptions (they replaced the back glass with a plastic barrier layer, although this is technically unproven); and they assumed even greater volumes and resulting cost reductions via, e.g., strategies like a front-end glass plant at 3 $\mathrm{GWp} / \mathrm{yr}$ plant size. In other words, the cost of the BOM assumed here should be considered conservative. For perspective: At 10\% efficiency, Table 4 is a BOM cost reduction from $55 \notin / \mathrm{Wp}$ today to about $40 \propto / \mathrm{Wp}$; but Keshner and Arya imply about 12 $\notin / \mathrm{Wp}$. That is a very large difference, and it would drive large differences in system cost for module technologies with different manufacturing cost/efficiency ratios. Future studies focused on BOM might be able to refine these results.

Next, the technology-specific (non-BOM) aspects of each approach were looked at, and a timeline was developed using a bottom-up approach. Expected technical improvements were delineated and their impacts assigned. Where possible, clear pathways and mechanistic cost reduction assumptions were used. For example, if layer thickness could be reduced from 3 microns to one micron for ultimate, practical (efficient) devices, equal improvement increments were chosen for the various production levels. Other projected improvements included faster semiconductor deposition speeds; better materials use; more uniform layers; higher quality layers; wider substrates; and incorporating a higher fraction of today's best cell efficiencies into future typical commercial modules. In addition, some volume economies were also assumed (e.g., in the capital equipment costs), though not as aggressively as in Keshner and Arya (2004). These projections were seeded into the spreadsheet at various levels of maturity and throughput for each of the major cases. The results were costs for the non-BOM of the technologies that varied as follows:

Table 6. Possible evolution of technology-specific (non-BOM) costs $\left(\$ / \mathrm{m}^{2}\right)$ by technology

\begin{tabular}{|l|l|l|l|l|l|l|}
\hline $\begin{array}{l}\text { Annual } \\
\text { output }\end{array}$ & $\begin{array}{l}\text { CIS/SS } \\
\text { (high } \\
\text { capital, } \\
\text { poor } \\
\text { materials) }\end{array}$ & $\begin{array}{l}\text { CIS/glass } \\
\text { (high } \\
\text { capital, } \\
\text { poor } \\
\text { materials) }\end{array}$ & $\begin{array}{l}\text { CIS/glass } \\
\text { (moderate } \\
\text { capital, } \\
\text { poor } \\
\text { materials) }\end{array}$ & CdTe & $\begin{array}{l}\text { a-Si/a-Si } \\
\text { Batch on } \\
\text { glass }\end{array}$ & $\begin{array}{l}\text { a-Si in- } \\
\text { line on } \\
\text { flexible } \\
\text { (SS) }\end{array}$ \\
\hline $\mathbf{2 5 ~ M W p ~}$ & 140 & 140 & 106 & 45 & 36 & 59 \\
\hline $\mathbf{5 0 ~ M W p ~}$ & 87 & 104 & 81 & 34 & 28 & 48 \\
\hline $\begin{array}{l}\mathbf{2 0 0} \\
\text { MWp }\end{array}$ & 71 & 72 & 64 & 28 & 24 & 40 \\
\hline $\mathbf{1 ~ G W p ~}$ & 36 & 41 & 32 & 16 & 15 & 24 \\
\hline $\begin{array}{l}\text { \%o } \\
\text { reduction }\end{array}$ & $74 \%$ & $71 \%$ & $70 \%$ & $65 \%$ & $58 \%$ & $59 \%$ \\
\hline
\end{tabular}

Note the spread in projected cost reductions from the " $25 \mathrm{MWp} / \mathrm{yr}$ " level to the " $1 \mathrm{GWp} / \mathrm{yr}$ " level. The amount for a-Si is least (and thus perhaps most conservative); 
CdTe in the middle; and CIS much larger. This relates to the assumed reduction in capital costs for the CIS; and the reduction in semiconductor materials costs (from thinner layers and better utilization) for the CdTe and CIS. However, it also means that the amorphous silicon projections could be viewed as less uncertain.

To get total module costs, these non-BOM costs were added to appropriate BOM commonalities for the different packaging and substrate designs; and then an ES\&H cost estimate for in-plant costs (and recycling for CdTe) were added (this was also in Table 4). Since it is likely that all PV modules will be recycled at large volumes, about $\$ 5 / \mathrm{m} 2$ will probably need to be added to the non-CdTe modules in future analyses. The total module costs in $\$ / \mathrm{m}^{2}$ are shown in Table 7.

Table 7. Possible evolution of total module costs by technology $(\$ / \mathrm{m} 2)$

\begin{tabular}{|l|l|l|l|l|l|l|}
\hline $\begin{array}{l}\text { Annual } \\
\text { output }\end{array}$ & $\begin{array}{l}\text { CIS/SS (high } \\
\text { capital, poor } \\
\text { materials) }\end{array}$ & $\begin{array}{l}\text { CIS/glass } \\
\text { (high capital, } \\
\text { poor } \\
\text { materials) }\end{array}$ & $\begin{array}{l}\text { CIS/glass } \\
\text { (moderate } \\
\text { capital, poor } \\
\text { materials) }\end{array}$ & CdTe & $\begin{array}{l}\text { a-Si/a-Si } \\
\text { Batch on } \\
\text { glass }\end{array}$ & $\begin{array}{l}\text { a-Si in-line } \\
\text { on flexible } \\
\text { (SS) }\end{array}$ \\
\hline $\mathbf{2 5 ~ M W p ~}$ & 230 & 210 & 170 & 110 & 94 & 130 \\
\hline $\mathbf{5 0} \mathbf{M W p}$ & 170 & 160 & 140 & 93 & 80 & 110 \\
\hline $\mathbf{2 0 0} \mathbf{M W p}$ & 140 & 130 & 120 & 82 & 70 & 99 \\
\hline $\mathbf{1 ~ G W p}$ & 100 & 91 & 82 & 65 & 57 & 77 \\
\hline \% reduction & $57 \%$ & $57 \%$ & $52 \%$ & $41 \%$ & $39 \%$ & $41 \%$ \\
\hline
\end{tabular}

Again, the cost reduction for CIS appears more optimistic (as a percentage change) than those for the other thin films, and this can be attributed to projected capital and materials cost reductions, especially for the evaporation approaches. It could also be attributed to the fact that the non-CIS technologies are all more mature and already in production.

But manufacturing cost is only half the story. The other half is module efficiency, and in many cases it has driven a bifurcation in approaches between optimizing manufacturing costs and optimizing efficiency.

Table 8 shows a projection of the evolution of commercial module efficiencies. It should be borne in mind that efficiency affects both the module cost and the system cost; it applies at both these levels to get the final value of a module in terms of the end-user (system cost, which is given below in Table 13). It can also have an impact in terms of specific applications: e.g., rooftop arrays are often area-limited, favoring higher efficiencies. Two rows at the end of Table 8 show the relative increase in module efficiency from today's levels; and a comparison between the projected long-term module efficiency and the best laboratory cell today. 
Table 8. Estimated commercial module efficiency evolution (total area, STC; stabilized a-Si)

\begin{tabular}{|l|l|l|l|l|l|l|}
\hline $\begin{array}{l}\text { Annual } \\
\text { output }\end{array}$ & $\begin{array}{l}\text { CIS/SS } \\
\text { (high } \\
\text { capital, poor } \\
\text { materials) }\end{array}$ & $\begin{array}{l}\text { CIS/glass } \\
\text { (high } \\
\text { capital, } \\
\text { poor } \\
\text { materials) }\end{array}$ & $\begin{array}{l}\text { CIS/glass } \\
\text { (moderate } \\
\text { capital, } \\
\text { poor } \\
\text { materials) }\end{array}$ & CdTe & $\begin{array}{l}\text { a-Si/a-Si } \\
\text { Batch on } \\
\text { glass }\end{array}$ & $\begin{array}{l}\text { a-Si in-line } \\
\text { on flexible } \\
\text { (SS) }\end{array}$ \\
\hline $\mathbf{2 5}$ MWp & $8.5 \%$ & $11 \%$ & $10 \%$ & $8.5 \%$ & $6 \%$ & $7 \%$ \\
\hline $\mathbf{5 0}$ MWp & $10 \%$ & $12 \%$ & $11.5 \%$ & $10 \%$ & $7 \%$ & $8 \%$ \\
\hline $\mathbf{2 0 0}$ MWp & $11.25 \%$ & $14 \%$ & $12.75 \%$ & $11.5 \%$ & $7.5 \%$ & $9 \%$ \\
\hline $\mathbf{1 ~ G W p}$ & $14 \%$ & $16 \%$ & $15.5 \%$ & $14 \%$ & $8.5 \%$ & $10.5 \%$ \\
\hline$\%$ increase & $65 \%$ & $45 \%$ & $55 \%$ & $65 \%$ & $42 \%$ & $50 \%$ \\
\hline $\begin{array}{l}\text { \% of today's } \\
\text { best cell }\end{array}$ & $\begin{array}{l}72 \%(\text { of } \\
19.5 \%)\end{array}$ & $82 \%$ & $\begin{array}{l}79 \%(\text { of } \\
19.5)\end{array}$ & $\begin{array}{l}85 \%(\mathrm{of} \\
16.5 \%)\end{array}$ & $\begin{array}{l}68 \%(\mathrm{of} \\
12.5 \%)\end{array}$ & $\begin{array}{l}84 \%(\text { of } \\
12.5 \%)\end{array}$ \\
\hline
\end{tabular}

An up-to-date table of module efficiencies taken from websites is provided in the Appendix, Table A-1. In some cases, numbers differ slightly from those in Table 8.

The technologies highlighted in Tables 1-8 are those in first-time or prototype production. But they were not the only technology options studied. Studying others brings up a whole new level of uncertainty, and estimates for these must be viewed with increased skepticism. Not only is uncertainty greater, but the choices needed to make the technologies cost-effective at all are much riskier technically. For example, are any of the new technologies stable? Since we can't say, we assume they are, just to get a start at comparison. But if they are not, then these comparisons are unusable and even misleading if used out of context. (To a lesser degree there remain reliability issues in the $2 \mathrm{G}$ thin films, too, and even in newly modified x-Si products.) There are numerous favorable assumptions made to make cost estimates of emerging $3 \mathrm{G}$ thin films. It is crucial that the reader not compare them directly to more mature technologies without this in mind.

The newer technologies share the BOM of the other technologies. This is a helpful grounding that can result in insights. The first obvious question: Can a new technology even come close to being cost-competitive with those already examined? If not, why should we try to develop them?

There were basically two categories of alternate technologies: further variations on the classic second-generation ( $2 \mathrm{G}$ ) thin films (CIS, CdTe, and thin-Si) but not yet in pilot production (e.g., CIS precursor inks, microcrystalline $\mathrm{Si}$ ); and so-called third-generation (3G) thin films such as dye-sensitized cells, plastics, quantum dots, and tandem CIS/CdTe-like cells.

Table 9 shows a summary of the estimated cost evolution of these less-mature approaches, for just the non-BOM portions (the BOM was assumed to be the same as the others, depending on designs). Since all of these will start production later than current options, they were assumed to be introduced at larger throughput levels just to be competitive. However, this may not be their actual development path. Note the very low non-BOM cost estimates for the $3 \mathrm{G}$ thin films - this is their presumed strength. Complications from unknown process requirements or future large-scale production problems were not included and may raise these estimates to much higher levels. Such complications may also exist for the other technologies, but with a reduced probability (since they are better known and more mature). Thus all these estimates make the key assumption that everything on the cost side will go well for these new technologies. 
Table 9. Alternative thin film module options, estimated cost evolution of non-BOM only $(\$ / \mathrm{m} 2)$

\begin{tabular}{|c|c|c|c|c|c|c|c|c|}
\hline $\begin{array}{l}\text { Annual } \\
\text { output }\end{array}$ & $\begin{array}{l}\text { CIS/glass } \\
\text { moderate } \\
\text { capital, } \\
\text { good } \\
\text { materials }\end{array}$ & $\begin{array}{l}\text { CIS on } \\
\text { foil low } \\
\text { capital } \\
\text { ok } \\
\text { material } \\
\text { s }\end{array}$ & $\begin{array}{l}\text { Thin } x- \\
\text { Si (in- } \\
\text { line) on } \\
\text { glass }\end{array}$ & $\begin{array}{l}\text { Dye cells } \\
\text { on glass }\end{array}$ & $\begin{array}{l}\text { Plastic or } \\
\text { Quantum } \\
\text { dots on } \\
\text { plastic }\end{array}$ & $\begin{array}{l}\text { 4-terminal } \\
\text { "CdTe/CIS" }\end{array}$ & $\begin{array}{l}\text { 2-terminal } \\
\text { "CdTe/CIS" }\end{array}$ & $\begin{array}{l}\text { 2-terminal } \\
\text { CdTe } \\
\text { /quantum } \\
\text { dots }\end{array}$ \\
\hline 25 MWp & $\mathrm{n} / \mathrm{A}$ & $\mathrm{n} / \mathrm{A}$ & $\mathrm{n} / \mathrm{A}$ & $\mathrm{n} / \mathrm{A}$ & $\mathrm{n} / \mathrm{A}$ & $\mathrm{n} / \mathrm{A}$ & $\mathrm{n} / \mathrm{A}$ & $\mathrm{n} / \mathrm{A}$ \\
\hline 50 MWp & 47 & 41 & 59 & 34 & $\mathrm{n} / \mathrm{A}$ & $\mathrm{n} / \mathrm{A}$ & $\mathrm{n} / \mathrm{A}$ & $\mathrm{n} / \mathrm{A}$ \\
\hline $200 \mathrm{MWp}$ & 35 & 30 & 42 & 23 & 20 & $\mathrm{n} / \mathrm{A}$ & $\mathrm{n} / \mathrm{A}$ & $\mathrm{n} / \mathrm{A}$ \\
\hline $1 \mathrm{GWp}$ & 22 & 17 & 23 & 13 & 9 & 49 & 53 & 28 \\
\hline
\end{tabular}

The "CdTe/CIS" nomenclature is used to indicate a future, successful combination of high gap CdTe and low-gap CIS; however, this is unproven and not optimized at this juncture and should be considered high risk (see Table 10).

Table 10 shows the efficiency assumptions for these alternate technologies, which are certainly open to debate. Notice the radically greater spread in future module efficiency estimates versus current status. But this is unavoidable, as any new technology will always start out very low; and without great progress, it will simply disappear.

Table 10. Alternative thin film module options, estimated efficiency (\%) evolution

\begin{tabular}{|c|c|c|c|c|c|c|c|c|}
\hline $\begin{array}{l}\text { Annual } \\
\text { output }\end{array}$ & $\begin{array}{l}\text { CIS/glass } \\
\text { moderate } \\
\text { capital, } \\
\text { good } \\
\text { materials }\end{array}$ & $\begin{array}{l}\text { CIS/foil } \\
\text { low } \\
\text { capital, ok } \\
\text { materials }\end{array}$ & $\begin{array}{l}\text { Thin } x- \\
\text { Si (in- } \\
\text { line) on } \\
\text { glass }\end{array}$ & $\begin{array}{l}\text { Tandem } \\
\text { Dye cells } \\
\text { on glass }\end{array}$ & $\begin{array}{l}\text { Plastic or } \\
\text { Quantum } \\
\text { dots on } \\
\text { plastic }\end{array}$ & $\begin{array}{l}\text { 4-terminal } \\
\text { "CdTe/CIS" }\end{array}$ & $\begin{array}{l}\text { 2-terminal } \\
\text { "CdTe/CIS" }\end{array}$ & $\begin{array}{l}\text { 2-terminal } \\
\text { CdTe } \\
\text { /quantum } \\
\text { dots }\end{array}$ \\
\hline $25 \mathrm{MWp}$ & $\mathrm{n} / \mathrm{A}$ & $\mathrm{n} / \mathrm{A}$ & $\mathrm{n} / \mathrm{A}$ & $\mathrm{n} / \mathrm{A}$ & $\mathrm{n} / \mathrm{A}$ & $\mathrm{n} / \mathrm{A}$ & $\mathrm{n} / \mathrm{A}$ & $\mathrm{n} / \mathrm{A}$ \\
\hline 50 MWp & 8 & 7 & 6.5 & 6 & $\mathrm{n} / \mathrm{A}$ & $\mathrm{n} / \mathrm{A}$ & $\mathrm{n} / \mathrm{A}$ & $\mathrm{n} / \mathrm{A}$ \\
\hline $200 \mathrm{MWp}$ & 10 & 10 & 8 & 7 & 5 & $\mathrm{n} / \mathrm{A}$ & $\mathrm{n} / \mathrm{A}$ & $\mathrm{n} / \mathrm{A}$ \\
\hline $1 \mathrm{GWp}$ & 14 & 14 & 11 & 10 & 8 & 20 & 19 & 17 \\
\hline $\begin{array}{l}\text { \% of } \\
\text { today's } \\
\text { best cell }\end{array}$ & $\begin{array}{l}72 \% \text { (of } \\
19.5 \% \text { ) }\end{array}$ & $\begin{array}{l}72 \% \text { (of } \\
19.5 \% \text { ) }\end{array}$ & $\begin{array}{l}91 \% \text { (of } \\
11 \% \text { ) }\end{array}$ & $\begin{array}{l}83 \% \text { (of } \\
12 \% \text { ) }\end{array}$ & $\begin{array}{l}160 \% \text { (of } \\
5 \% \text { ) }\end{array}$ & $\begin{array}{l}137 \% \text { (of } \\
15 \% \text { ) }\end{array}$ & $\mathrm{n} / \mathrm{A}$ & $\mathrm{n} / \mathrm{A}$ \\
\hline $\begin{array}{l}\text { Comment } \\
\text { on } \\
\text { assumed } \\
\text { efficiency } \\
\text { levels }\end{array}$ & $\begin{array}{l}13 \% \text { cell } \\
\text { today }\end{array}$ & $\begin{array}{l}11 \% \text { cell } \\
\text { today }\end{array}$ & $\begin{array}{l}11 \% \text { cell } \\
\text { today }\end{array}$ & $\begin{array}{l}12 \% \text { cell } \\
\text { today }\end{array}$ & $\begin{array}{l}5 \% \text { cell } \\
\text { today }\end{array}$ & $\begin{array}{l}15 \% \text { cell } \\
\text { today }\end{array}$ & Just starting & $\begin{array}{l}\text { Not yet } \\
\text { tried }\end{array}$ \\
\hline
\end{tabular}

Table 11 shows a qualitative assessment of relative risk among the technologies. It is based on the gap between current efficiency levels and the long-term efficiencies needed for success; and on technical challenges to scale-up, pilot production, or commercial success, including stability issues. These risks need to be borne in mind when assessing real status and potential. Due to similar challenges, many early thin film options have already fallen by the wayside despite high hopes, and this is the way the higher-risk options should be viewed until proven otherwise. 
Table 11. Estimated relative technical risks of the thin film technologies ( 1 is lowest risk) to reach their ultimate cost goals (at $1 \mathrm{GW} / \mathrm{yr}$ production)

\begin{tabular}{|l|l|l|}
\hline Technology & $\begin{array}{l}\text { Relative } \\
\text { Risk }\end{array}$ & Comments on major risks \\
\hline a-Si/a-Si/glass batch & 1.5 (least) & Commercial \\
\hline a-Si/flexible in line & 1.5 & Commercial \\
\hline CdTe & 1.5 & Commercial \\
\hline $\begin{array}{l}\text { CIS/glass moderate-high capital } \\
\text { poor materials }\end{array}$ & 2.5 & A few MW \\
\hline $\begin{array}{l}\text { CIS/glass moderate capital good } \\
\text { materials }\end{array}$ & 3.5 & A few MW \\
\hline $\begin{array}{l}\text { CIS/foil good capital moderate } \\
\text { materials }\end{array}$ & 3.5 & A few MW \\
\hline In-line x-Si/glass & 3.5 & $\begin{array}{l}\text { a-Si/x-Si phase control, higher } \\
\text { efficiency and rates, larger areas }\end{array}$ \\
\hline Dye-sensitized/glass & 4.5 & $\begin{array}{l}\text { Stability, module design, higher } \\
\text { efficiencies }\end{array}$ \\
\hline 4-terminal "CdTe CIS" (glass) & 7 & $\begin{array}{l}\text { High-efficiency top cell at 1.7eV, top- } \\
\text { cell transparency }\end{array}$ \\
\hline 2-terminal "CdTe CIS" (glass) & 8 & $\begin{array}{l}\text { High-efficiency top cell at 1.7eV, not } \\
\text { killing first cell while making 2 } \\
\text { top-cell transparency }\end{array}$ \\
\hline Quantum dots plastic & 10 & Stability, efficiency \\
\hline $\begin{array}{l}\text { 2-terminal CdTe \& quantum dots } \\
\text { glass }\end{array}$ & 10 (worst) & $\begin{array}{l}\text { Current-matched quantum dot cell, } \\
\text { stability, top-cell transparency }\end{array}$ \\
\hline
\end{tabular}

For the long-term scenario ( $1 \mathrm{GWp} / \mathrm{yr}$ production), a breakdown of the module manufacturing costs by materials; labor; utilities and rent; maintenance; and capital is given in the following figures. Note that this is only the active (non-BOM) portion of the cost, and as such must be combined with BOM, module efficiency, ES\&H, and final BOS costs to reach system costs. For example, this picture gives the most favorable picture of the $3 \mathrm{G}$ thin films. 


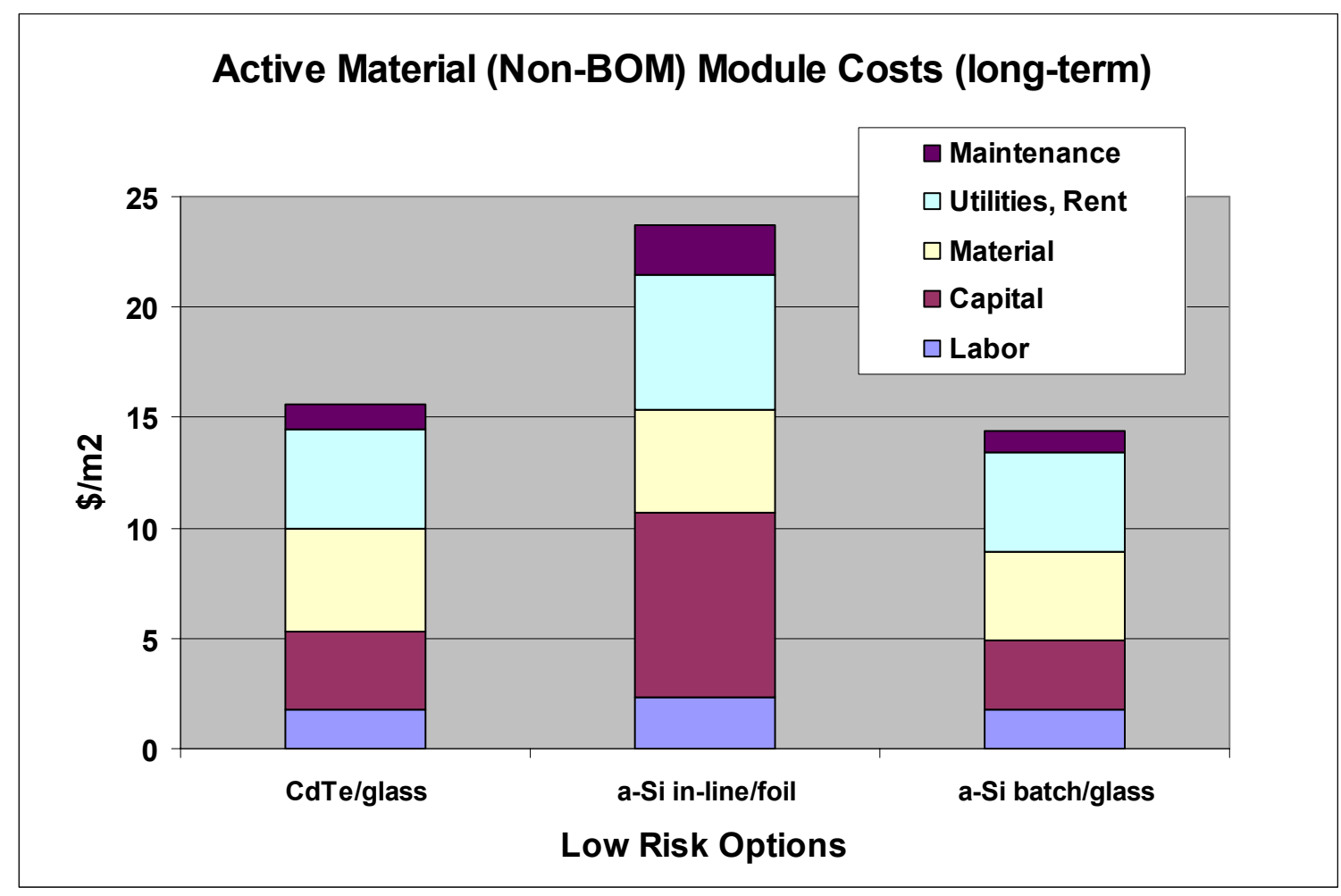

Figure 1. For low-risk options, a breakdown of module manufacturing costs $\left(\$ / \mathrm{m}^{2}\right)$ for the active junctions layers (non-BOM) for the long-term scenario (1GW/yr).

Note that the utilities are rather high. Even though thin film modules have energy paybacks of about a year, a year outside is about $170 \mathrm{kWh} / \mathrm{m} 2$ in an average location. At a nickel a $\mathrm{kWh}$, that's about $\$ 8.5 / \mathrm{m} 2$ in electricity cost. But this is shared with the BOM (especially its embedded energy) and will be lower with time (especially for thinner layers, where cost can come down more than half). But even $60 \mathrm{kWh}\left(3 \$ / \mathrm{m}^{2}\right)$ is a large cost in Figure 1. This also shows how low the other non-BOM costs are.

From Figure 1, it would appear that batch a-Si has a major advantage over in-line a-Si (from having lower capital costs). However, once all the other factors (BOM, BOS, module efficiency are included; see Table 14) this apparent major advantage almost completely disappears. Then when the advantages of flexible modules show up at the system level, the advantage is reversed: the a-Si flexible module is a more competitive product. This pattern occurs over and over in thin films: apparent advantages at one level of cost or efficiency can be misleading if other factors are not included in the judgment. In fact, this is the general give and take throughout PV technologies: cost on one side, efficiency on the other (and stability as a general requirement). Each technology makes its 'bet' on its strength; but in the end, a combination of strengths is required; e.g., CdTe may not be the best in every category, but it is nearly the best in all of them, leading to the lowest system costs among the thin films examined (see Table 14). 


\section{Active Material (Non-BOM) Module Costs (long-term)}

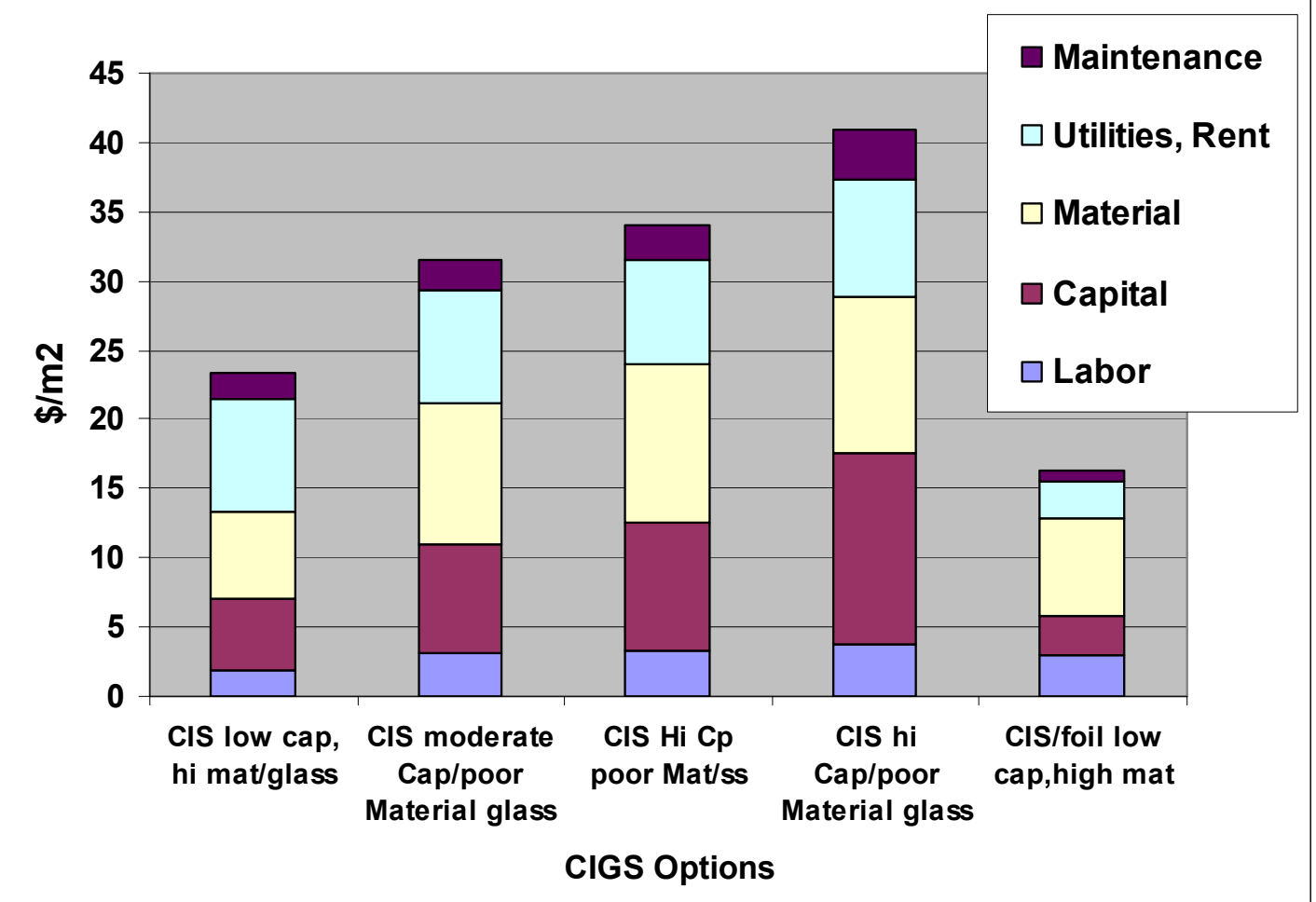

Figure 2. For CIS-alloy options, a breakdown of module manufacturing costs $\left(\$ / \mathrm{m}^{2}\right)$ for the active junctions layers (non-BOM) for the long-term scenario (1GW/yr).

The CIS approaches (Figure 2) run the gamut from high-cost, high-efficiency to low-cost, low-efficiency, and everything in between. The higher capital cost technologies are in pilot production. Others are just demonstrating cells. Although most of the costs for the CIS approaches are higher than those in Figure 1, CIS is known for its high efficiencies, thus making the potential of the options in Figure 2 attractive.

The thin film $\mathrm{x}-\mathrm{Si}$ (in Figure 3) is betting on the strength of crystalline silicon as a known technology to surpass a-Si in efficiency, though this may be difficult (due to the indirect band gap of $\mathrm{x}-\mathrm{Si}$ ). Similarly, there are substantial variations in approaches to thin film $\mathrm{x}-$ $\mathrm{Si}$; some choose higher temperatures and may incur extra substrate costs; others at lower temperatures might not be able to make as efficient devices. These are the type of cost uncertainties implicit in the less-well-developed options. The dye-sensitized approach is a radically different PV technology that has the potential for low non-BOM, while maintaining efficiency. However, a minor shortfall in the dye cell's relative efficiency or some special design requirement in the modules would easily consume this apparent cost advantage, even at the module level. Stability is also an issue, since little is known now about actual dye-cell modules outdoors. 


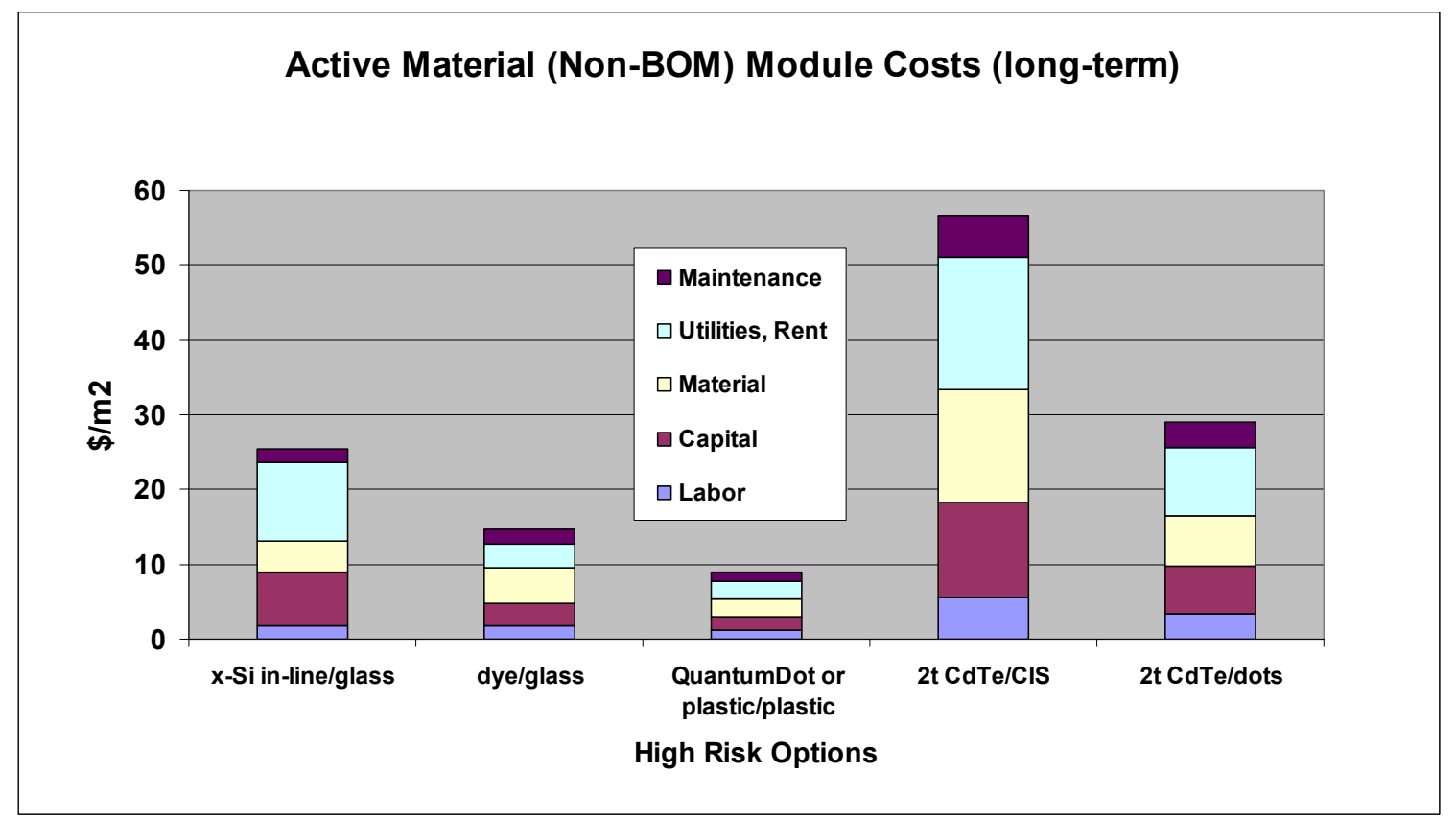

Figure 3. For high-risk options, a breakdown of module manufacturing costs $\left(\$ / \mathrm{m}^{2}\right)$ for the active junctions layers (non-BOM) for the long-term scenario $(1 \mathrm{GW} / \mathrm{yr})$.

It is interesting to contemplate how options with very different non-BOM expenses (e.g., the "CdTe/CIS" 2-terminal multijunction versus the quantum dot module, which is over six times lower) can be about the same cost at the system level (see Table 14). That is, when BOM is added to both, and then the relative efficiency of the multijunction is assumed to be more than double that of the quantum dot module, the system results actually favor the multijunction. Yet without considering the BOM, BOS, and relative efficiencies, one would miss this.

As can be seen from Table 16 (below), the high-risk alternatives (except one hybrid version that has never been tried) are hard pressed to approach the potential of the simpler, low- and moderate-risk single-junction CdTe and CIS options. This brings into question their value as research paths. Why work on them if they do not even provide an advantage over lower-risk choices? Perhaps this is too harsh. Perhaps as part of buildings and avoiding most BOM and BOS, the lower cost options could do well; but of course, such applications are open to the less-risky ones, too. In the end, some of the high-risk technologies may find a home as special aspects of the other technologies, e.g., the quantum dot technology as a low-cost bottom cell to scavenge wasted long-wavelength photons at minimal cost. Why might this work when the quantum dot design by itself might not? Because very little extra BOM cost is incurred for the 2-terminal design; whereas by itself, the low-efficiency quantum dot technology would have to carry the entire BOM. And the non-BOM cost of the quantum dot cell may be very small.

Combining all the above derived and assumed numbers, it is possible to summarize the resulting evolution in module cost (in dollars per watt) for each technology (Table 12) and then rank them by system price (Table 14) the final arbiter of PV module value. 
Table 12. Projected module cost evolution of thin films $(\$ / W p)^{1}$

\begin{tabular}{|c|c|c|c|c|}
\hline & $25 \mathrm{MWp}$ & $50 \mathrm{MWp}$ & $200 \mathrm{MWp}$ & $1 \mathrm{GWp}$ \\
\hline CdTe/glass & 1.28 & 0.94 & 0.73 & 0.47 \\
\hline $\begin{array}{l}\text { 2-terminal } \\
\text { CdTe \& } \\
\text { quantum dots }\end{array}$ & $\mathrm{n} / \mathrm{A}$ & $\mathrm{n} / \mathrm{A}$ & $\mathrm{n} / \mathrm{A}$ & 0.47 \\
\hline $\begin{array}{l}\text { CIS/glass } \\
\text { moderate } \\
\text { capital, good } \\
\text { materials use }\end{array}$ & $\mathrm{n} / \mathrm{A}$ & 1.32 & 0.89 & 0.51 \\
\hline $\begin{array}{l}\text { CIS/glass } \\
\text { moderate } \\
\text { capital, poor } \\
\text { materials use }\end{array}$ & 1.73 & 1.24 & 0.93 & 0.53 \\
\hline $\begin{array}{l}\text { 2-terminal } \\
\text { "CdTe CIS" }\end{array}$ & $\mathrm{n} / \mathrm{A}$ & $\mathrm{n} / \mathrm{A}$ & $\mathrm{n} / \mathrm{A}$ & 0.53 \\
\hline $\begin{array}{l}\text { CIS on glass hi } \\
\text { capital, poor } \\
\text { materials use }\end{array}$ & 1.87 & 1.37 & 0.91 & 0.57 \\
\hline $\begin{array}{l}\text { 4-terminal } \\
\text { "CdTe CIS" }\end{array}$ & $\mathrm{n} / \mathrm{A}$ & $\mathrm{n} / \mathrm{A}$ & $\mathrm{n} / \mathrm{A}$ & 0.57 \\
\hline $\begin{array}{l}\text { Dye- } \\
\text { sensitized/glass }\end{array}$ & $\mathrm{n} / \mathrm{A}$ & 1.4 & 0.96 & 0.58 \\
\hline $\begin{array}{l}\text { CIS on SS low } \\
\text { capital, high } \\
\text { materials use }\end{array}$ & $\mathrm{n} / \mathrm{A}$ & 1.71 & 1 & 0.59 \\
\hline $\begin{array}{l}\text { In-line } x- \\
\text { Si/glass }\end{array}$ & $\mathrm{n} / \mathrm{A}$ & 1.62 & 1.06 & 0.59 \\
\hline a-Si batch/glass & 1.56 & 1.21 & 0.97 & 0.67 \\
\hline $\begin{array}{l}\text { CIS on SS, hi } \\
\text { capital poor } \\
\text { materials use }\end{array}$ & 2.67 & 1.68 & 1.27 & 0.71 \\
\hline a-Si in-line/SS & 1.88 & 1.44 & 1.13 & 0.73 \\
\hline $\begin{array}{l}\text { Quantum dots } \\
\text { or plastic/plastic }\end{array}$ & $\mathrm{n} / \mathrm{A}$ & $\mathrm{n} / \mathrm{A}$ & 1.6 & 0.8 \\
\hline
\end{tabular}

${ }^{1} \mathrm{BOM}$, non-BOM, and ES\&H are included; sales, marketing, management, R\&D, warranty, shipping, taxes, insurance, and profit are not included in these direct manufacturing costs.

The system-level comparison requires including both balance of system (BOS) costs and a mark-up for all the missing marketing, management, other sundries, and profit.

BOS costs vary with application. For this analysis, large systems that contribute to $\mathrm{CO}_{2}$ reduction were chosen as most apt. Two such systems are large, commercial roofs; and ground-mounted systems. Table 13 shows the BOS assumptions for large, ground mounted systems. A system today that might be considered an example of such designs is the Springerville, AZ, installation managed by Tucson Electric Power (private communication, Hansen 2005; and Mason 2004). It is important to note that low module 
efficiencies incur a large, area-related penalty (more modules are needed to make the same output) in ground-mounted systems. (We will see later that this is usually but not universally true for commercial rooftop systems.)

Table 13. Assumed BOS cost evolution for large, ground-mounted systems

\begin{tabular}{|c|c|c|c|c|c|c|c|c|}
\hline & \multicolumn{2}{|c|}{ Hardware } & \multicolumn{2}{|c|}{$\begin{array}{l}\text { Non-hardware } \\
\text { (Design,prep,install, } \\
\text { ship...) }\end{array}$} & \multicolumn{2}{|c|}{ BOS total } & \multirow{2}{*}{$\begin{array}{l}\text { indirect: } \\
\text { profit \& } \\
\text { marketing } \\
\text { Dollar- } \\
\text { related } \\
\text { multiplier }\end{array}$} & \multirow[t]{2}{*}{$\begin{array}{l}\text { O\&M } \\
\phi / k W h\end{array}$} \\
\hline & $\begin{array}{l}\text { Area- } \\
\text { related }\end{array}$ & $\begin{array}{l}\text { Power- } \\
\text { related }\end{array}$ & $\begin{array}{l}\text { Area- } \\
\text { related }\end{array}$ & $\begin{array}{l}\text { Power- } \\
\text { related }\end{array}$ & $\begin{array}{l}\text { Area- } \\
\text { related }\end{array}$ & $\begin{array}{l}\text { Power- } \\
\text { related }\end{array}$ & & \\
\hline $25 \mathrm{MW}$ & 60 & 0.4 & 30 & 0.1 & 90 & 0.5 & $25 \%$ & 0.3 \\
\hline $50 \mathrm{MW}$ & 50 & 0.35 & 20 & 0.09 & 70 & 0.44 & $20 \%$ & 0.2 \\
\hline $200 \mathrm{MW}$ & 40 & 0.3 & 15 & 0.08 & 55 & 0.38 & $15 \%$ & 0.1 \\
\hline $1 \mathrm{GW}$ & 30 & 0.2 & 10 & 0.07 & 40 & 0.27 & $10 \%$ & 0.05 \\
\hline
\end{tabular}

Table 14-15 show the same evolution of assumptions for large, commercial rooftop systems. However in this case, two kinds of modules and designs are assumed: glass modules with racks, and flexible laminates without racks. The difference is that the arearelated costs for the flexible modules is much lower due to the absence of racks and also simpler set up and installation. The reduced area-related costs allow lower efficiency, flexible laminates to still be competitive with $\mathrm{x}$-Si modules on glass. It also reveals that thin films made on glass modules are not as competitive as those made on flexible substrates for this application.

Table 14. Assumed BOS cost evolution of large, commercial-rooftop systems (glass modules)

\begin{tabular}{|c|c|c|c|c|c|c|c|c|}
\hline & \multicolumn{2}{|c|}{ Hardware } & \multicolumn{2}{|c|}{$\begin{array}{l}\text { Non-hardware } \\
\text { (Design,prep,install, } \\
\text { ship...) }\end{array}$} & \multicolumn{2}{|c|}{ BOS total } & \multirow{2}{*}{$\begin{array}{l}\text { indirect: } \\
\text { profit \& } \\
\text { marketing } \\
\text { Dollar- } \\
\text { related } \\
\text { multiplier }\end{array}$} & \multirow[t]{2}{*}{$\begin{array}{l}\text { O\&M } \\
\phi / k W h\end{array}$} \\
\hline & $\begin{array}{l}\text { Area- } \\
\text { related }\end{array}$ & $\begin{array}{l}\text { Power- } \\
\text { related }\end{array}$ & $\begin{array}{l}\text { Area- } \\
\text { related }\end{array}$ & $\begin{array}{l}\text { Power- } \\
\text { related }\end{array}$ & $\begin{array}{l}\text { Area- } \\
\text { related }\end{array}$ & $\begin{array}{l}\text { Power- } \\
\text { related }\end{array}$ & & \\
\hline $25 \mathrm{MW}$ & 90 & 0.6 & 45 & 0.15 & 135 & 0.77 & $40 \%$ & 0.9 \\
\hline $50 \mathrm{MW}$ & 80 & 0.525 & 30 & 0.13 & 110 & 0.66 & $32 \%$ & 0.6 \\
\hline $200 \mathrm{MW}$ & 70 & 0.45 & 23 & 0.11 & 93 & 0.56 & $24 \%$ & 0.3 \\
\hline $1 \mathrm{GW}$ & 60 & 0.3 & 15 & 0.09 & 75 & 0.39 & $16 \%$ & 0.15 \\
\hline
\end{tabular}


Table 15. Assumed BOS cost evolution of large, commercial-rooftop systems (flexible laminates)

\begin{tabular}{|c|c|c|c|c|c|c|c|c|}
\hline & \multicolumn{2}{|c|}{ Hardware } & \multicolumn{2}{|c|}{$\begin{array}{l}\text { Non-hardware } \\
\text { (Design,prep,install, } \\
\text { ship...) }\end{array}$} & \multicolumn{2}{|c|}{ BOS total } & \multirow{2}{*}{$\begin{array}{l}\text { indirect: } \\
\text { profit \& } \\
\text { marketing } \\
\text { Dollar- } \\
\text { related } \\
\text { multiplier }\end{array}$} & \multirow[t]{2}{*}{$\begin{array}{l}\text { O\&M } \\
\phi / k W h\end{array}$} \\
\hline & $\begin{array}{l}\text { Area- } \\
\text { related }\end{array}$ & $\begin{array}{l}\text { Power- } \\
\text { related }\end{array}$ & $\begin{array}{l}\text { Area- } \\
\text { related }\end{array}$ & $\begin{array}{l}\text { Power- } \\
\text { related }\end{array}$ & $\begin{array}{l}\text { Area- } \\
\text { related }\end{array}$ & $\begin{array}{l}\text { Power- } \\
\text { related }\end{array}$ & & \\
\hline 25 MW & 63 & 0.6 & 36 & 0.15 & 99 & 0.75 & $40 \%$ & 0.6 \\
\hline $50 \mathrm{MW}$ & 56 & 0.5325 & 24 & 0.13 & 80 & 0.66 & $32 \%$ & 0.4 \\
\hline $200 \mathrm{MW}$ & 49 & 0.45 & 18 & 0.11 & 67 & 0.56 & $24 \%$ & 0.2 \\
\hline $1 \mathrm{GW}$ & 42 & 0.3 & 12 & 0.09 & 54 & 0.39 & $16 \%$ & 0.1 \\
\hline
\end{tabular}

The next table (16) compares technologies at the system level in $\$ / \mathrm{Wp}$ for a large, ground-mounted system. For this purpose, an estimated price has been developed from the various costs. The price includes everything: module, BOS, sales, marketing, management, R\&D, warranty, shipping, taxes, insurance, profit, and O\&M. The assumed margin for the systems is reduced with time and size, and becomes quite low, as one might believe that at the desired multi-100s-of-GWp/yr level for the large-volume estimates (and that is the point of this analysis), overheads, for example, will be tiny, as they are in other energy commodity industries like coal.

Table 16. Comparison of thin film system prices for ground-mounted, large systems $(\$ / W p$ DC) based on the above data and assumptions

\begin{tabular}{|l|l|l|l|l|l|}
\hline & $\mathbf{2 5} \mathbf{M W p}$ & $\mathbf{5 0} \mathbf{M W p}$ & $\mathbf{2 0 0} \mathbf{M W p}$ & $\mathbf{1} \mathbf{G W p}$ & $\begin{array}{l}\text { Relative } \\
\text { Risk }\end{array}$ \\
\hline $\begin{array}{l}\text { 2-terminal } \\
\text { CdTe \& } \\
\text { quantum dots }\end{array}$ & $\mathrm{n} / \mathrm{A}$ & $\mathrm{n} / \mathrm{A}$ & $\mathrm{n} / \mathrm{A}$ & 1.08 & High \\
\hline $\begin{array}{l}\text { 2-terminal } \\
\text { "CdTe CIS" }\end{array}$ & $\mathrm{n} / \mathrm{A}$ & $\mathrm{n} / \mathrm{A}$ & $\mathrm{n} / \mathrm{A}$ & 1.11 & High \\
\hline CdTe/glass & 3.55 & 2.5 & 1.83 & 1.12 & Low \\
\hline $\begin{array}{l}\text { 4-terminal } \\
\text { "CdTe CIS" }\end{array}$ & $\mathrm{n} / \mathrm{A}$ & $\mathrm{n} / \mathrm{A}$ & $\mathrm{n} / \mathrm{A}$ & 1.14 & High \\
\hline $\begin{array}{l}\text { CIS/glass } \\
\text { moderate cap, } \\
\text { poor material }\end{array}$ & 3.9 & 2.76 & 2 & 1.16 & Moderate \\
\hline $\begin{array}{l}\text { CIS/glass } \\
\text { moderate cap, } \\
\text { good material }\end{array}$ & $\mathrm{n} / \mathrm{A}$ & 3.17 & 2.09 & 1.18 & Moderate \\
\hline $\begin{array}{l}\text { CIS/glass hi } \\
\text { cap, poor } \\
\text { material }\end{array}$ & 4 & 2.87 & 1.93 & 1.2 & Moderate \\
\hline $\begin{array}{l}\text { CIS/SS low } \\
\text { cap, good } \\
\text { material }\end{array}$ & $\mathrm{n} / \mathrm{A}$ & 3.78 & 2.23 & 1.26 & Moderate \\
\hline
\end{tabular}




\begin{tabular}{|l|l|l|l|l|l|}
\hline $\begin{array}{l}\text { In-line x- } \\
\text { Si/glass }\end{array}$ & $\mathrm{n} / \mathrm{A}$ & 3.77 & 2.45 & 1.34 & Moderate \\
\hline $\begin{array}{l}\text { Dye- } \\
\text { sensitized/glass }\end{array}$ & $\mathrm{n} / \mathrm{A}$ & 3.55 & 2.39 & 1.37 & Moderate \\
\hline $\begin{array}{l}\text { CIS/SS } \\
\text { moderate cap, } \\
\text { poor material }\end{array}$ & 5.28 & 3.39 & 2.46 & 1.4 & Moderate \\
\hline a-Si/SS in-line & 4.58 & 3.32 & 2.46 & 1.52 & Low \\
\hline $\begin{array}{l}\text { a-Si/glass } \\
\text { batch }\end{array}$ & 4.45 & 3.24 & 2.42 & 1.55 & Low \\
\hline $\begin{array}{l}\text { Quantum dots } \\
\text { or plastic on } \\
\text { plastic }\end{array}$ & $\mathrm{n} / \mathrm{A}$ & $\mathrm{n} / \mathrm{A}$ & 3.5 & 1.7 & High \\
\hline $\begin{array}{l}\text { Possible x-Si } \\
\text { wafer }\end{array}$ & 4.59 & 3.84 & 3.22 & 2.62 & Low \\
\hline
\end{tabular}

A comment on Table 16. Why aren't systems selling for the low prices seen here? First, of all, the options that are lower than $\mathrm{x}-\mathrm{Si}$ (at $\$ 4.59 / \mathrm{Wp}$ ), only CdTe is in manufacturing. The price of systems is also 'what the market will bear'. However, the CdTe system price does seem low, given current experience. This may indicate a flaw in the analysis (perhaps the area-related BOS is higher than assumed here) or larger margins for these systems than taken into account here. But also recall that no single company's approach is the basis of these estimates. Also, perhaps existing CdTe manufacturing is not quite as optimized for $25 \mathrm{MWp} / \mathrm{yr}$ production as assumed here.

Table 17. Comparison of thin film system prices for ground-mounted, large systems (\$/Wp DC) with risks and barriers

\begin{tabular}{|l|l|l|l|l|}
\hline & $\mathbf{2 5} \mathbf{M W p}$ & $\mathbf{1 ~ G W p}$ & $\begin{array}{l}\text { Projected } \\
\text { Improvement } \\
\text { from Today's } \\
\text { Price (\%) }\end{array}$ & Comments and barriers \\
\hline $\begin{array}{l}\text { 2-terminal } \\
\text { CdTe \& } \\
\text { quantum dots }\end{array}$ & n/A & 1.08 & $100 \%$ & $\begin{array}{l}\text { Never been tried; totally } \\
\text { unproven; quantum dot or } \\
\text { plastic cell unproven }\end{array}$ \\
\hline $\begin{array}{l}\text { 2-terminal } \\
\text { "CdTe CIS" }\end{array}$ & n/A & 1.11 & $100 \%$ & $\begin{array}{l}\text { Probably not worth it for this } \\
\text { application (if either subcell } \\
\text { works they will be used } \\
\text { instead) }\end{array}$ \\
\hline CdTe/glass & 3.6 & 1.12 & $67 \%$ & $\begin{array}{l}\text { Thinner CdTe, } \\
\text { manufacturability of thin CdS } \\
\text { design; best combination of } \\
\text { least risk, most reward for } \\
\text { this application }\end{array}$ \\
\hline $\begin{array}{l}\text { 4-terminal } \\
\text { "CdTe CIS" }\end{array}$ & n/A & 1.14 & $100 \%$ & $\begin{array}{l}\text { Not worth it for this } \\
\text { application (if either subcell } \\
\text { works they will be used } \\
\text { instead) }\end{array}$ \\
\hline
\end{tabular}




\begin{tabular}{|c|c|c|c|c|}
\hline $\begin{array}{l}\text { CIS/glass } \\
\text { moderate cap, } \\
\text { poor material } \\
\end{array}$ & 3.96 & 1.16 & $70 \%$ & $\begin{array}{l}\text { Lower capital costs; thinner } \\
\text { CIS; unproven manufacturing }\end{array}$ \\
\hline $\begin{array}{l}\text { CIS/glass } \\
\text { moderate cap, } \\
\text { good material }\end{array}$ & $\mathrm{n} / \mathrm{A}$ & 1.18 & $100 \%$ & $\begin{array}{l}\text { Unproven efficiency; } \\
\text { unproven manufacturing }\end{array}$ \\
\hline $\begin{array}{l}\text { CIS/glass hi } \\
\text { cap, poor } \\
\text { material }\end{array}$ & 4.03 & 1.2 & $70 \%$ & $\begin{array}{l}\text { Lower capital; thinner CIS; } \\
\text { unproven manufacturing }\end{array}$ \\
\hline $\begin{array}{l}\text { CIS/SS low } \\
\text { cap, good } \\
\text { material }\end{array}$ & $\mathrm{n} / \mathrm{A}$ & 1.26 & $100 \%$ & $\begin{array}{l}\text { Better for rooftops; efficiency } \\
\text { unproven; thinner CIS; } \\
\text { unproven manufacturing }\end{array}$ \\
\hline $\begin{array}{l}\text { In-line } x- \\
\text { Si/glass }\end{array}$ & $\mathrm{n} / \mathrm{A}$ & 1.34 & $100 \%$ & $\begin{array}{l}\text { Higher efficiency, lower } \\
\text { capital; unproven } \\
\text { manufacturing }\end{array}$ \\
\hline $\begin{array}{l}\text { Dye- } \\
\text { sensitized/gla } \\
\text { ss }\end{array}$ & $\mathrm{n} / \mathrm{A}$ & 1.37 & $100 \%$ & $\begin{array}{l}\text { Unproven efficiency and } \\
\text { stability; unproven } \\
\text { manufacturing; encapsulation } \\
\text { issues }\end{array}$ \\
\hline $\begin{array}{l}\text { CIS/SS } \\
\text { moderate cap, } \\
\text { poor material }\end{array}$ & 5.35 & 1.4 & $75 \%$ & $\begin{array}{l}\text { Better for rooftops; lower } \\
\text { capital, higher efficiency, } \\
\text { thinner CIS; unproven } \\
\text { manufacturing }\end{array}$ \\
\hline a-Si/SS in-line & 4.66 & 1.52 & $66 \%$ & $\begin{array}{l}\text { Better for rooftops; lower } \\
\text { capital }\end{array}$ \\
\hline $\begin{array}{l}\text { a-Si/glass } \\
\text { batch }\end{array}$ & 4.53 & 1.55 & $65 \%$ & Higher efficiency \\
\hline $\begin{array}{l}\text { Quantum } \\
\text { dots or plastic } \\
\text { on plastic } \\
\end{array}$ & $\mathrm{n} / \mathrm{A}$ & 1.7 & $100 \%$ & $\begin{array}{l}\text { Completely unproven } \\
\text { efficiency and stability }\end{array}$ \\
\hline $\begin{array}{l}\text { Possible } x-S i \\
\text { wafer }\end{array}$ & 4.59 & 2.62 & $43 \%$ & $\begin{array}{l}\text { Better for rooftops because of } \\
\text { efficiency; technically more } \\
\text { mature (less improvement } \\
\text { expected) }\end{array}$ \\
\hline
\end{tabular}




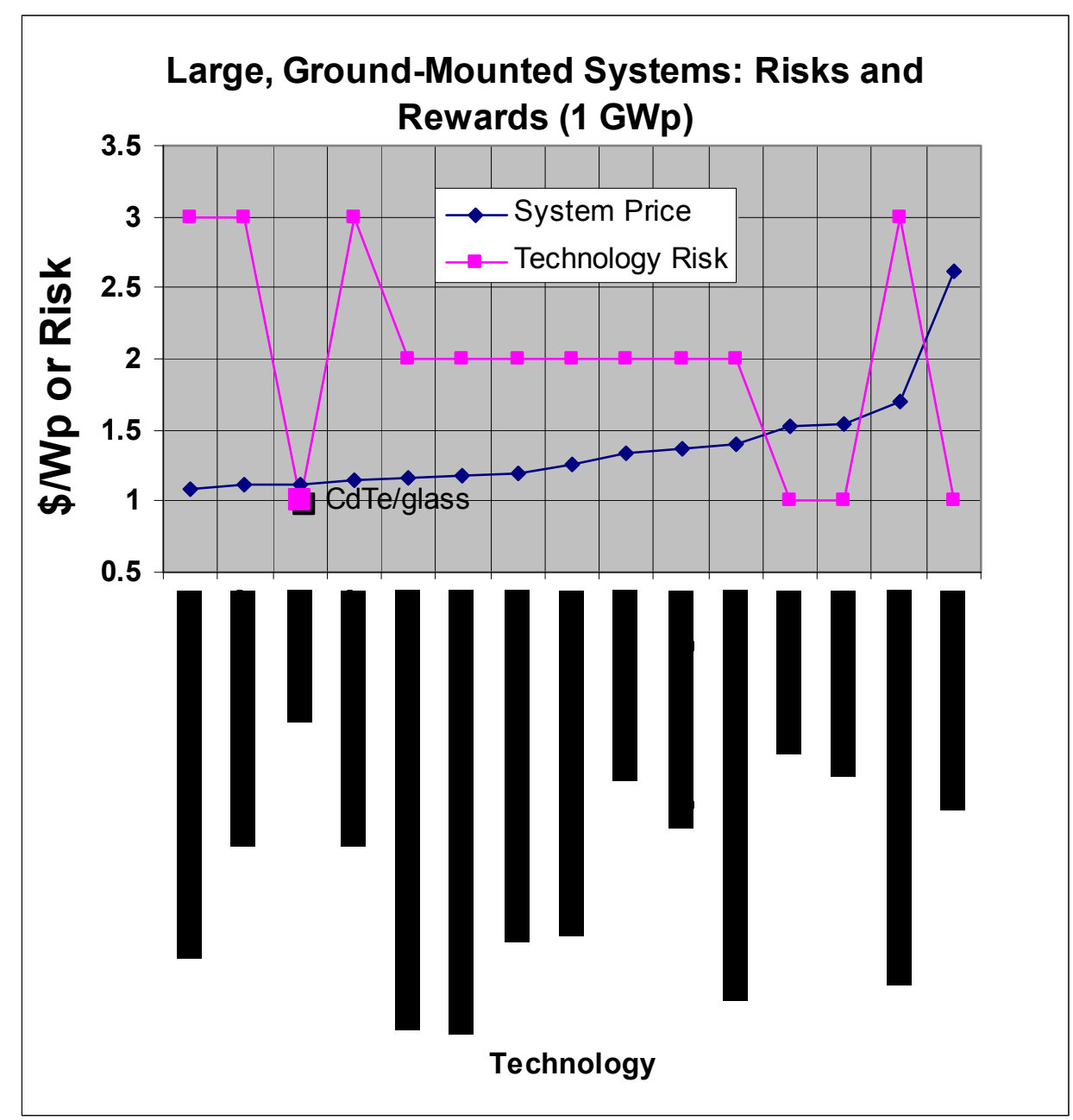

Figure 4. Risk and Reward by Technology for Large, Ground-Mounted Systems (1 GWp); the CdTe Technology Stands Out for Low Cost and Low Risk

Table 18 shows the comparison of thin films for large, commercial rooftop systems, in this case including the balance of system advantage of flexible modules. 
Table 18. Comparison of thin film system prices for large, commercial rooftop systems (\$/Wp DC)

\begin{tabular}{|c|c|c|c|c|c|}
\hline & 25 MWp & 50 MWp & 200 MWp & 1 GWp & $\begin{array}{l}\text { Relative } \\
\text { Risk }\end{array}$ \\
\hline $\begin{array}{l}\text { 2-terminal } \\
\text { CdTe \& } \\
\text { quantum dots }\end{array}$ & $\mathrm{n} / \mathrm{A}$ & $\mathrm{n} / \mathrm{A}$ & $\mathrm{n} / \mathrm{A}$ & 1.51 & High \\
\hline $\begin{array}{l}\text { 2-terminal } \\
\text { "CdTe CIS" }\end{array}$ & $\mathrm{n} / \mathrm{A}$ & $\mathrm{n} / \mathrm{A}$ & $\mathrm{n} / \mathrm{A}$ & 1.52 & High \\
\hline $\begin{array}{l}\text { 4-terminal } \\
\text { "CdTe CIS" }\end{array}$ & $\mathrm{n} / \mathrm{A}$ & $\mathrm{n} / \mathrm{A}$ & $\mathrm{n} / \mathrm{A}$ & 1.54 & High \\
\hline $\begin{array}{l}\text { CIS/SS low } \\
\text { cap, good } \\
\text { material }\end{array}$ & $\mathrm{n} / \mathrm{A}$ & 4.63 & 2.78 & 1.58 & Moderate \\
\hline CdTe/glass & 5.07 & 3.58 & 2.61 & 1.61 & Low \\
\hline $\begin{array}{l}\text { CIS/glass } \\
\text { moderate cap, } \\
\text { poor material }\end{array}$ & 5.36 & 3.78 & 2.75 & 1.63 & Moderate \\
\hline $\begin{array}{l}\text { CIS/glass hi } \\
\text { cap, poor } \\
\text { material }\end{array}$ & 5.39 & 3.88 & 2.64 & 1.66 & Moderate \\
\hline $\begin{array}{l}\text { CIS/glass } \\
\text { moderate cap, } \\
\text { good material }\end{array}$ & $\mathrm{n} / \mathrm{A}$ & 4.43 & 2.94 & 1.67 & Moderate \\
\hline $\begin{array}{l}\text { CIS/SS } \\
\text { moderate cap, } \\
\text { poor material }\end{array}$ & 6.41 & 4.15 & 3 & 1.73 & Moderate \\
\hline a-Si/SS in-line & 5.66 & 4.1 & 3.04 & 1.9 & Low \\
\hline $\begin{array}{l}\text { In-line } x- \\
\text { Si/glass }\end{array}$ & $\mathrm{n} / \mathrm{A}$ & 5.25 & 3.44 & 1.92 & Moderate \\
\hline $\begin{array}{l}\text { Dye- } \\
\text { sensitized/glass }\end{array}$ & $\mathrm{n} / \mathrm{A}$ & 5.04 & 3.42 & 1.99 & Moderate \\
\hline $\begin{array}{l}\text { Quantum dots } \\
\text { or plastic on } \\
\text { plastic }\end{array}$ & $\mathrm{n} / \mathrm{A}$ & $\mathrm{n} / \mathrm{A}$ & 4.36 & 2.16 & High \\
\hline $\begin{array}{l}\text { a-Si/glass } \\
\text { batch }\end{array}$ & 6.38 & 4.65 & 3.48 & 2.5 & Low \\
\hline $\begin{array}{l}\text { Possible } x-S i \\
\text { wafer }\end{array}$ & 5.96 & 4.88 & 4.0 & 3.16 & Low \\
\hline
\end{tabular}


Table 19. Comparison of thin film system prices for large, commercial systems

(\$/Wp DC) with risks and barriers

\begin{tabular}{|c|c|c|c|c|}
\hline & 25 MWp & 1 GWp & $\begin{array}{l}\text { Projected } \\
\text { Improvement } \\
\text { from Today's } \\
\text { Price (\%) }\end{array}$ & Comments and barriers \\
\hline $\begin{array}{l}\text { 2-terminal } \\
\text { CdTe \& } \\
\text { quantum } \\
\text { dots }\end{array}$ & $\mathrm{n} / \mathrm{A}$ & 1.51 & $100 \%$ & $\begin{array}{l}\text { Never been tried; totally } \\
\text { unproven; quantum dot or } \\
\text { plastic cell unproven }\end{array}$ \\
\hline $\begin{array}{l}\text { 2-terminal } \\
\text { "CdTe CIS" }\end{array}$ & $\mathrm{n} / \mathrm{A}$ & 1.52 & $100 \%$ & $\begin{array}{l}\text { Probably not worth it for } \\
\text { this application (if either } \\
\text { subcell works they will be } \\
\text { used instead) }\end{array}$ \\
\hline $\begin{array}{l}\text { 4-terminal } \\
\text { "CdTe CIS" }\end{array}$ & $\mathrm{n} / \mathrm{A}$ & 1.54 & $100 \%$ & $\begin{array}{l}\text { Not worth it for this } \\
\text { application (if either } \\
\text { subcell works they will be } \\
\text { used instead) }\end{array}$ \\
\hline $\begin{array}{l}\text { CIS/SS low } \\
\text { cap, good } \\
\text { material }\end{array}$ & $\mathrm{n} / \mathrm{A}$ & 1.58 & $100 \%$ & $\begin{array}{l}\text { Better for rooftops; } \\
\text { efficiency unproven; } \\
\text { thinner CIS; unproven } \\
\text { manufacturing }\end{array}$ \\
\hline CdTe/glass & 5.07 & 1.61 & $66 \%$ & $\begin{array}{l}\text { Thinner CdTe, } \\
\text { manufacturability of thin } \\
\text { CdS design; best } \\
\text { combination of least risk, } \\
\text { most reward for this } \\
\text { application }\end{array}$ \\
\hline $\begin{array}{l}\text { CIS/glass } \\
\text { moderate } \\
\text { cap, poor } \\
\text { material }\end{array}$ & 5.36 & 1.63 & $69 \%$ & $\begin{array}{l}\text { Lower capital costs; } \\
\text { thinner CIS; unproven } \\
\text { manufacturing }\end{array}$ \\
\hline $\begin{array}{l}\text { CIS/glass hi } \\
\text { cap, poor } \\
\text { material }\end{array}$ & 5.39 & 1.66 & $100 \%$ & $\begin{array}{l}\text { Lower capital; thinner CIS; } \\
\text { unproven manufacturing }\end{array}$ \\
\hline $\begin{array}{l}\text { CIS/glass } \\
\text { moderate } \\
\text { cap, good } \\
\text { material }\end{array}$ & $\mathrm{n} / \mathrm{A}$ & 1.67 & $100 \%$ & $\begin{array}{l}\text { Unproven efficiency; } \\
\text { unproven manufacturing }\end{array}$ \\
\hline $\begin{array}{l}\text { CIS/SS } \\
\text { moderate } \\
\text { cap, poor } \\
\text { material }\end{array}$ & 6.41 & 1.73 & $74 \%$ & $\begin{array}{l}\text { Better for rooftops; lower } \\
\text { capital, higher efficiency, } \\
\text { thinner CIS; unproven } \\
\text { manufacturing }\end{array}$ \\
\hline $\begin{array}{l}\text { a-Si/SS in- } \\
\text { line }\end{array}$ & 5.66 & 1.9 & $66 \%$ & $\begin{array}{l}\text { Better for rooftops; lower } \\
\text { capital }\end{array}$ \\
\hline In-line $x-$ & $\mathrm{n} / \mathrm{A}$ & 1.92 & $100 \%$ & Higher efficiency, lower \\
\hline
\end{tabular}




\begin{tabular}{|l|l|l|l|l|}
\hline Si/glass & & & & $\begin{array}{l}\text { capital; unproven } \\
\text { manufacturing }\end{array}$ \\
\hline $\begin{array}{l}\text { Dye- } \\
\text { sensitized/gl } \\
\text { ass }\end{array}$ & n/A & 1.99 & $100 \%$ & $\begin{array}{l}\text { Unproven efficiency and } \\
\text { stability; unproven } \\
\text { manufacturing; } \\
\text { encapsulation issues }\end{array}$ \\
\hline $\begin{array}{l}\text { Quantum } \\
\text { dots or } \\
\text { plastic on } \\
\text { plastic }\end{array}$ & n/A & 2.16 & $100 \%$ & $\begin{array}{l}\text { Completely unproven } \\
\text { efficiency and stability }\end{array}$ \\
\hline $\begin{array}{l}\text { a-Si/glass } \\
\text { batch }\end{array}$ & 6.38 & 2.5 & $65 \%$ & Higher efficiency \\
\hline $\begin{array}{l}\text { Possible x-Si } \\
\text { wafer }\end{array}$ & 5.96 & 3.16 & $47 \%$ & $\begin{array}{l}\text { Better for rooftops because } \\
\text { of efficiency; technically } \\
\text { more mature (less } \\
\text { improvement expected) }\end{array}$ \\
\hline
\end{tabular}

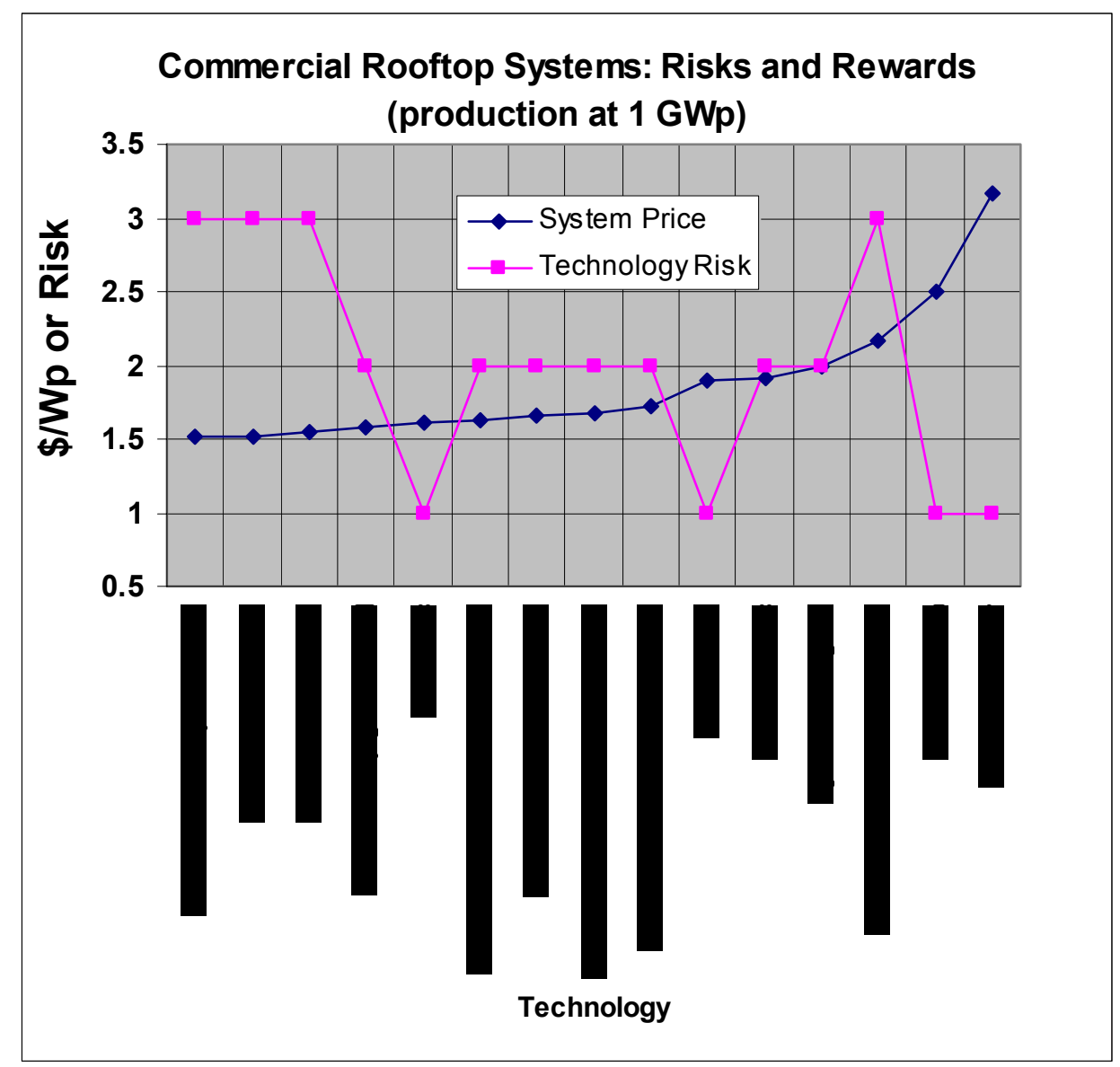

Figure 5. Risks and Rewards for Commercial Rooftops (1 GWp)

Some observations about the tables and figures:

- Although CIS and CdTe dominate the lowest, long-term costs by about 30\%, inherent issues with indium and tellurium availability mean that thinner cells 
(about 0.5-1 micron) would help maximize their contribution to the TW Challenge (see next section). It is not clear they can reach the efficiencies of Table 8 at reduced thicknesses. CIS and CdTe alone are probably not going to be the only surviving PV options. But they may be the most economical.

- CdTe has the opportunity to dominate all markets, but is especially attractive for ground-mounted systems. For residential roof top systems, especially small ones, $\mathrm{x}$-Si may still be more attractive due to its higher efficiency.

- CIS is as attractive as CdTe for the long-term, but it is about a 'generation' in factory size behind CdTe and a-Si. This lag may make it hard for CIS to fully realize its potential. Risks are also higher with CIS, and not all key challenges may have been overcome (first-time manufacturing at the $25 \mathrm{MWp} / \mathrm{yr}$ level does not exist). Thus long-term comparisons that seem to show equality with CdTe are not complete without this risk assessment.

- Despite good potential, the CIS/CdTe multijunction may not play a role longterm, because it would have about the same system price as the separate singlejunctions but would use more rare indium and tellurium per output watt (while also increasing manufacturability complexity, offset somewhat by higher efficiencies). Intermediate-term, it might find a niche where efficiency outweighs system cost, e.g., on small roofs, but this is not a key market.

- The "top cell CdTe/quantum dot bottom cell" (current-matched, two-terminal approach) provides some minor, potential cost and efficiency advantage over the single-junction CdTe or CIS separately; though counter-intuitive, it is a potentially sensible way to scavenge low-energy photons if the bottom cell can be added cheaply (e.g., using quantum dots, plastic, or dye cells), without damaging the CdTe top cell. This is an ultra-high risk, speculative option that has never even been fabricated in the lab.

- Thin film silicon approaches (including both amorphous and nanocrystalline silicon) separate into two categories: those on glass and those that are flexible. The ones on glass all have system prices between traditional $\mathrm{x}$-Si itself and the CIS-CdTe complex. However, near-term, the thin Si technologies on glass have a hard time competing because they are not leaders in any category, trailing both x$\mathrm{Si}$ and $\mathrm{CdTe}$. However, the flexible thin Si (e.g., amorphous silicon on stainless steel) is competitive at the system level versus $\mathrm{x}$-Si for large, metal roofs - an important market

- Dye cells on glass have many aspects in common with thin silicon, except they seem to have lower capital costs. However, dye cells have not been manufactured, and skepticism remains about their reliability outdoors. Aspects of module design to overcome stability issues may lead to added costs.

- The other 3G thin films (quantum dots, plastics) are hampered by severely low efficiencies. They simply may be too inefficient to ever be usable except for specialty applications indoors. Even if they progress in terms of efficiency, they are so immature that they may completely disappear due to technical risks of scale-up and outdoor reliability. To be competitive, these type of thin films need efficiencies almost as high as the others, and proven stability. 
- It is unclear if any of the more exotic $3 \mathrm{G}$ options have materials availability issues at this point (ruthenium dye is a clear issue, but future designs may eliminate it; this should be studied).

- For comparison (and a sanity check), an 15.6\% traditional x-Si module costing $\$ 1.85 / \mathrm{Wp}$, based on the most aggressive BOS case above, would have a long-term system cost of $\$ 2.62 / \mathrm{Wp}$ - which, given the current leadership of $\mathrm{x}-\mathrm{Si}$ in PV, means that $\mathrm{x}$-Si will likely be around as a competitor for the entire projected period. Only thin films truly executing the above scenarios might change this. In practice, with expected vastly expanding markets for the foreseeable future, $\mathrm{x}-\mathrm{Si}$ and thin films will likely share the marketplace.

- For the most part, there are some critical issues in each thin film that could seriously hamper success; and those who are involved will have to tackle them while also maintaining explosive manufacturing growth. There is no certainty this will happen successfully, and some 'skepticism' factor should probably be added to the above cost projections (e.g., in comparison with the crystalline silicon technologies, with their lower risk) to reflect this.

- On the other hand, anything that would move the goals of a technology in a much more positive direction (e.g., a major efficiency advance over the stated levels) would also affect the leadership among thin films and in PV. Certainly, the predicted long-term efficiencies of the technologies are something that could change and be very important.

- Any new, lower-cost packaging designs beyond those assumed in this study would probably reduce the cost of all modules for which they could be used, assuming reliability could be maintained for any of them (but see next bullet).

- Given their lack of competitive advantage in conventional applications, the $3 \mathrm{G}$ options should rededicate themselves to much higher efficiency strategies (e.g., creative multijunction structures) and to see whether their specific designs (e.g., lower processing temperatures) allow a unique potential for simpler, less-costly BOM than other thin films. The hurdle of outdoor reliability also remains very challenging.

- This analysis shows groupings of technologies, with single-junction CIS and CdTe looking the best because of their combination of high efficiency and low manufacturing cost. However, within groupings, it would be premature to use the results to decide that one approach is clearly better than another, given the inherent uncertainties and the need for successful execution. Indeed, there is a similarity of long-term potential prices if different approaches are well executed and the message may not be their potential similarity of cost, but the similarity of the hurdles needed to get there.

For an average US solar location like Kansas City, $\$ 1 / \mathrm{Wp}-\mathrm{DC}$ is equivalent to about 6 $\phi / \mathrm{kWh}$ (see Appendix 1 for levelized energy calculations). Thus the range of costs in Tables 16 and 18 (about $\$ 1.1$ for ground mounted; $\$ 1.5$ for rooftop) implies about 6-9 $\notin / \mathrm{kWh}$ AC PV electricity. Especially for larger systems, it might be expected that the sunnier locations would predominate, and in that case costs would be more favorable. Overall, these costs appear within range needed to meet the TW Challenge for PV, 
especially when it is recalled that rather conservative assumptions were made for the BOM aspects of the modules and BOS for systems.

\subsection{Other Aspects of the "TW Challenge"}

So far, the potential to achieve very low cost has been emphasized. That is critical to making PV cost-effective enough to be used economically. But there are other factors to the "TW Challenge." The main one is materials availability. To have 10-20 TW of PV energy installed by mid-century, we need about 50-100 TW-peak, due to the $15 \%-25 \%$ capacity factor of PV. To accomplish this by 2065, for example, would require very high initial growth, resulting in about $4000 \mathrm{GW}$-peak of annual PV production in 2065. This means that about $15 \mathrm{TW}$ (not peak) of PV would be installed and producing electricity in 2065 (given an assumed average lifespan of 30 years). Figure 6 shows a growth rate for $\mathrm{PV}$ to reach $75 \mathrm{TWp}$ installed in 2065.

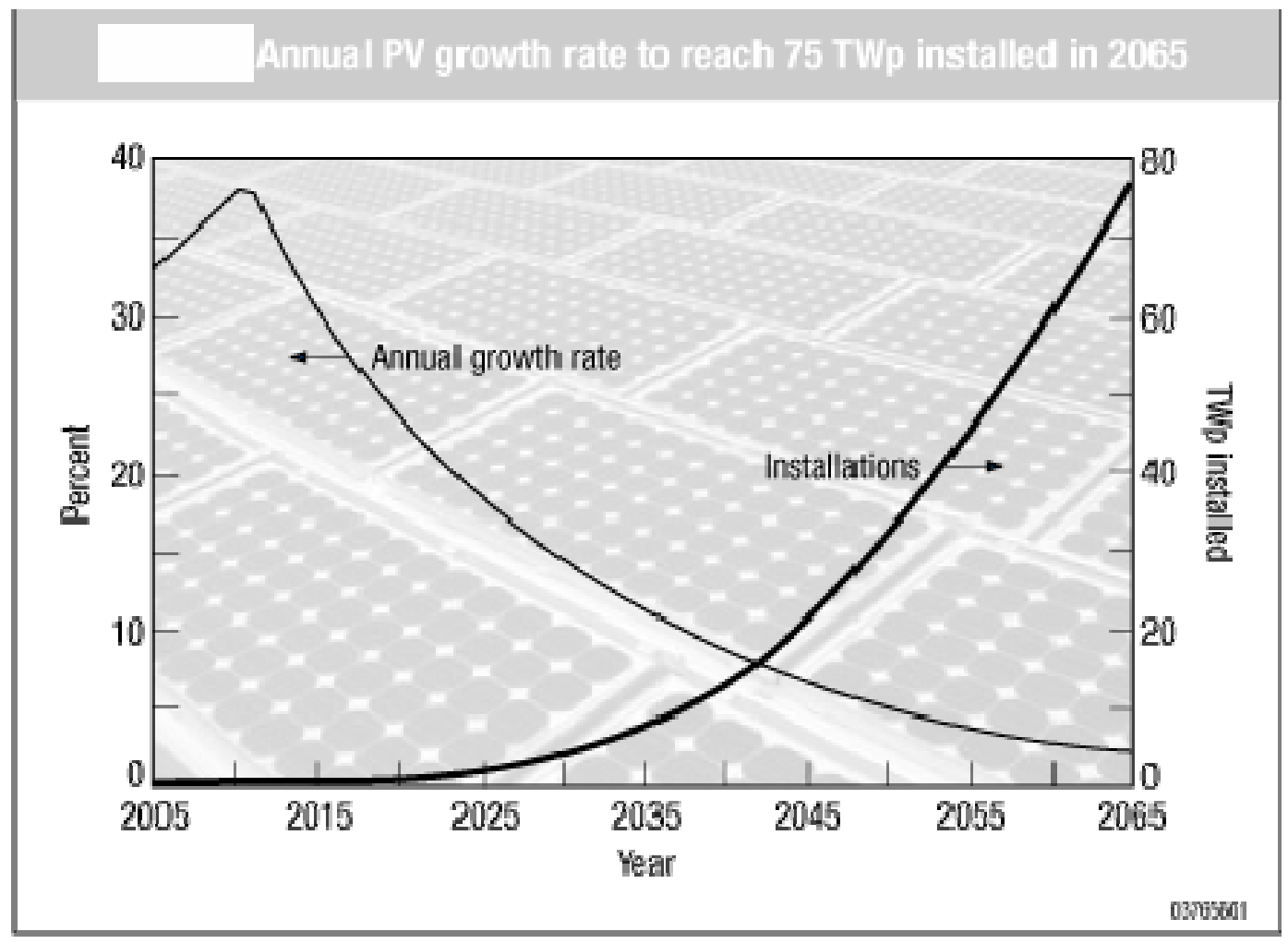

Figure 6. A physically reasonable world annual PV sales growth rate that would reach $75 \mathrm{TWp}$ installed in 2065. PV has grown at over $30 \%$ per year over the last six years (and over $50 \%$ in 2004).

The materials requirements to meet this challenge have been studied in an NREL FAQ (NREL 2005 http://www.nrel.gov/ncpv/pvmenu.cgi?site+ncpv\&idx=3\&body=faq.html) by this author, which is summarized here: 
We do not expect shortages of most basic materials (glass, steel, aluminum, and plastic) except perhaps copper if its current extraction growth rate falls. If this happens, the problem might be alleviated by changes in BOS design to use other conductors.

We do foresee possible availability issues for a few of the semiconductor materials. NREL (2005) shows that only the CdTe and CIS technologies might be affected; the thin film silicon technologies are not limited, even those with germanium (there are major amounts of unused byproduct $\mathrm{Ge}$ in aluminum, coal, and zinc ore). Newer, $3 \mathrm{G}$ technologies need to be studied and are not included in the FAQ or this discussion.

Given that CdTe and CIS are important low-cost technologies, Table 20 summarizes the potential installed volumes of CIS and CdTe given an optimistic scenario of complete recycling and thinner layers ( 0.5 micron). Note that the thickness of today's CIS and CdTe PV is about 1-3 microns. Record efficiencies in these materials (at 2-3 micron thicknesses or more) are $16.5 \%$ for CdTe and $19.5 \%$ for CIS. So far, non-optimized 1micron CIS cells have reached about $17 \%$ at NREL (Ramanathan et al 2005); and 0.9micron CdTe cells have reached about $11 \%$ at U. Toledo (Gupta 2001; Gupta and Compaan 2005, in press); submicron cells are planned (even down to 0.25 micron), and some work is already being done (Ernst et al. 2003). To-date this has not been an area of much research, because current module costs have not yet been optimized for semiconductor materials costs. However, as thickness has now been identified as a key criterion for TW production, NREL has recently shifted some funding into this area.

Table 20 gives CIS and CdTe production by 2065 by assuming (1) all existing amounts (beyond current non-PV demand, itself assumed growing at $1 \% / \mathrm{yr}$ ) are available for use, and within PV (2) there is $100 \%$ materials use, and (3) complete recycling. Photovoltaic materials are not used-up the way fuels are; they can be fully re-used in new devices. Most data in Table 20 is derived from Andersson (2000) and Sanden (2003) and USGS web pages. The final amount in TWp (right column) is found by dividing the total cumulative amount of feedstock available between now and 2065 by the amount needed per TWp. 
Table 20. Potential installed TWp of CIS and CdTe in 2065 (with complete recycling)

\begin{tabular}{|l|l|l|l|l|l|}
\hline & $\begin{array}{l}\text { Primary } \\
\text { metal } \\
\text { and its } \\
\text { assumed } \\
\text { growth }\end{array}$ & $\begin{array}{l}\text { Percent } \\
\text { byproduct } \\
\text { currently } \\
\text { unused in } \\
\text { primary } \\
\text { metal }\end{array}$ & $\begin{array}{l}\text { Cumulative } \\
\text { amount in 2065 } \\
\text { (MT) using } \\
\text { assumed } \\
\text { extraction growth } \\
\text { rates }\end{array}$ & $\begin{array}{l}\text { MT } \\
\text { required } \\
\text { per TWp }\end{array}$ & $\begin{array}{l}\text { Maximum } \\
\text { installed } \\
\text { in 2065 } \\
\text { (TWp) }\end{array}$ \\
\hline Indium & $\begin{array}{l}\mathrm{Zn}, \\
1 \% / \mathrm{yr}\end{array}$ & $77 \%$ & 100,000 & $5600^{\mathrm{b}}$ & $17 \mathrm{TWp}$ \\
\hline Selenium & $\begin{array}{l}\mathrm{Cu} \mathrm{\&} \\
\text { coal, } \\
1 \% / \mathrm{yr}\end{array}$ & $87 \%$ & $2,900,000$ & 9000 & $300 \mathrm{TWp}$ \\
\hline Tellurium & $\begin{array}{l}\mathrm{Cu}, \\
1 \% / \mathrm{yr}\end{array}$ & $96 \%$ & 330,000 & 11000 & $30 \mathrm{TWp}$ \\
\hline
\end{tabular}

${ }^{a}$ In all cases, most of the current byproduct is unused (Sanden 2003); assumes 15\% efficiency, 0.5 micron layers. Future research may allow reducing layer thickness further, as well as higher efficiencies, both of which would reduce materials demand. No feedstock sources beyond those given in the table are considered (e.g., tellurium mines).

${ }^{\mathrm{b}}$ Indium required in devices is reduced by $20 \%$ replacement by $\mathrm{Ga}$ (as in existing devices); future designs may include even larger substitutions. Assumes 15\% module efficiency and 0.5-micron-thick layers.

Future research may further reduce layer thickness and increase efficiencies, reducing materials demand. Notes: The amounts in the table assume steady growth along historical lines in $\mathrm{Cu}$ and $\mathrm{Zn}$ extraction. Of these, $\mathrm{Cu}$ seems more vulnerable to slowing over the next few decades. Also, the unused byproduct amounts are very uncertain: they are based on extrapolating average Te and In levels in the primary ores. However, actually processing this material to extract a high percentage of Te and In will be an economic challenge. For example, only $60 \%-80 \%$ of the base metal content is extracted. In addition, the available byproduct will be unused early in the growth of PV but must remain available for future processing as demand increases; this is currently not a normal procedure in the mining industry.

Amounts of tellurium or indium that could be mined as primary materials (not as byproducts) have not been included in Table 20. We do not know the potential size of such deposits. Especially for tellurium, a material with very small markets to-date, it seems possible there could be significant unexploited deposits. Such deposits could change the whole picture of materials availability for the CIS and CdTe technologies.

Because such possibilities are unknown, we limit ourselves to the values Table 20. Using a factor of 5 to reduce to TW (not peak) on the amounts in Table 20, CIS could contribute as much as $3.4 \mathrm{TW}$; and CdTe, as much as $6 \mathrm{TW}$ by 2065. This means that these technologies can each be considered capable of meeting the TW Challenge and effectively contribute to the reduction of climate change. The amounts are also a substantial fraction of the desired 10-20 TW amount (and of course, huge by any other measure; e.g., the size of US energy consumption is $3 \mathrm{TW}$ ). Possible additions from primary materials are not counted in this sum, so perhaps even more could be made. Further, a steady state should be attained around 2065 in which recycled modules and ongoing PV device improvements (thinner cells, higher performance) would stabilize the need for newly extracted materials after 2065. The need could actually decline. But to be prudent, we should not assume that CdTe and CIS will carry the entire load, alone, despite their potential economic leadership (and especially because CIS is still unproven in manufacturing).

The use of certain materials used to make thin film modules deserve a brief discussion. Although perceived as a problem by some, many studies show that no danger exists from 
making, using, or disposing/recycling CdTe modules (http://www.nrel.gov/cdte/ ; and especially Fthenakis 2004). There also apparently are no issues in terms of market acceptance. The biggest market for CdTe has been Germany, a country sensitive to environmental and heavy metal issues.

The CIS technology has an echo of this problem due to the presence of selenium, also an element that is viewed with concern (though its recent use as a food supplement has ameliorated perceptions greatly). Other PV technologies usually have smaller, parallel problems that are less obvious - e.g., the Pb solder in $\mathrm{x}-\mathrm{Si}$ technology, or the toxic/explosive gasses in thin film silicon. In fact, it is well accepted that no energy option, no matter how 'green', is totally without environmental impacts, especially on the $T W$ scale. The best known and perhaps most rational measures of environmental impact, energy and $\mathrm{CO}_{2}$ paybacks, are favorable for thin films (NREL 2005a) - about 1 year for the kind of large, thin film systems we are examining.

One other barrier often cited is the land area needed to supply TWs of PV. Actually, using the original Nate Lewis number of 125,000 TW of sunlight on the Earth's surface can easily dissuade us of this concern. Assuming that this falls evenly on land and sea, this is about 36,000 TW falling on land. Assuming we need $20 \mathrm{TW}$ of PV, and the PV systems only averaged $10 \%$ sunlight-to-electricity conversion, that would be $0.55 \%$ of the Earth's land area for modules. Assuming a (module/system area) packing factor of $40 \%$, this requires 2.5 times more land, or $1.4 \%$ of the land area. Today, $1.1 \%$ of the US land area is used for national defense (bases and bombing ranges) and $0.04 \%$ is used to raise Christmas trees. Not only is the use of $1.4 \%$ of land for PV not a serious burden for converting our energy infrastructure to solar, it is a positive advantage of PV (as stated in detail in the FAQ NREL 2005 a) because no other non- $\mathrm{CO}_{2}$ resource except nuclear has anywhere near the same level of energy density/unit area and ubiquity. The above analysis completely ignores the reduction in land area requirements that would result from using PV on rooftops or other existing structures.

\subsection{Risks and Perspective}

The analysis of major thin films tends to underestimate technical risks (despite Table 11) and subsequent comments. Risks are pervasive in thin film development, and major setbacks have already occurred. Perhaps the most universal cause is a lack of science base. Because thin films are almost always different from mainstream electronics materials (as opposed to $\mathrm{x}-\mathrm{Si}$, which shares much with the mainstream), thin film development is not much supported by scientific understanding outside of PV. Problems that might otherwise be trivial are magnified. Serious problems such as the StaeblerWronski Effect in a-Si, multi-element stoichiometry and uniformity in CIS, and defects and their interactions in CdTe and its contacts are even harder to overcome. Any efforts to follow-through on the development of thin films for major energy production should allocate some support to improving their science base if only to reduce the risks associated with explosive growth.

Indeed, the risks associated with explosive growth are paralleled by those of getting started. The existence of one good solar cell (say $10 \%-15 \%$ efficiency at $1 \mathrm{~cm}^{2}$ size) is a needed proof-of-concept; but it is still a factor of $10^{9}$ away from the size of the annual output (in square meters of module area) needed to make a successful technology at 25 
MWp/yr. Newcomers to thin films sometimes miss this developmental challenge, to their detriment. It implies both high technical and financial risk, making the period of scale-up often the most challenging. Producing TWs creates a second major scale-up challenge but only another factor of about $10^{5}$ to get to about $4000 \mathrm{GWp} / \mathrm{yr}$.

Further, for PV to be actually used for TWs of energy, PV electricity storage and PVsynthesized fuels (like water splitting or a reverse methanol fuel cell) will be needed. In addition to these technical and energy systems challenges, it will be favorable if PV costs could drop below even those outlined here. For that, further aggressive research work could be highly beneficial.

The point here is that due to substantial, ongoing financial and technical challenges (and the potential for great rewards), thin films need long-term, financial support from the private and public sectors to allow them to reach their potential. As this chapter should make clear, achieving that potential would be well worth the investment in terms of meeting the TW Challenge.

\subsection{References}

B. A. Andersson (now Sanden), 2000, "Materials availability for large-scale thin-film photovoltaics," Progress in Photovoltaics. V. 8: 61-76.

P.A. Basore, 2004, "Simplified Processing and Improved Performance of Crystalline Silicon on Glass Modules," Pacific Solar Pty Ltd, in $19^{\text {th }}$ European PV SEC, (http://www.nrel.gov/ncpv/thin film/pdfs/epvsec19.pdf) .

D.T. Colbert and R.E. Smalley, 2002, "Past, Present, and Future of Fullerene Nanotubes: Buckytubes." Perspectives of Fullerene Nanotechnology, 3-10, Kluwer Academic Publishers.

A.E. Delahoy, Y-M. Li, J. Anna Selvan, L. Chen, T. Varvar, H. Volltrauer, Energy Photovoltaics, Inc., 2004, "Massive Parallel Processing for Low Cost a-Si Production," (http://www.nrel.gov/ncpv/thin film/pdfs/delahoy a-si.pdf).

R.A. Enzenroth, K.L. Barth, and W.S. Sampath, 2004, "Continuous In-Line Processing of CdS/CdTe Devices: Progress Towards Consistent Stability," 19th European Photovoltaic Solar Energy Conference and Exhibition, Colorado State University (http://www.nrel.gov/ncpv/thin film/pdfs/csm 2004 euro pv paper.pdf).

First Solar press release, May 2005, "First Solar Announces Insurance Policy to Fund Solar Module Reclamation and Recycling Expenses at End of Product Life," http://www.firstsolar.com/pdf/MD-5704\%20EU\%20First\%20Solar\%20Announces\%20Insurance\%20Policy.pdf

V. Fthenakis, 2004, "Life Cycle Impact Analysis of Cadmium in CdTe PV production," Renewable and Sustainable Energy Reviews, 8 (2004) 303-334.

S. Guha and J. Yang, 2003, High-Efficiency Amorphous Silicon Alloy Based Solar Cells and Modules Annual Technical Progress Report, May 30, 2002 - May 31, 2003, United Solar Systems Corp.; NREL report (http://www.nrel.gov/ncpv/thin film/pdfs/ussc may2003.pdf). 
Aklesh Gupta, 2001, "Effect of CdTe thickness reduction," Materials Research Society Symposium Proceedings, v 668, page H6.4.1.

A. Gupta and A. Compaan, 2005, Proceedings of the IEEE PV Specialists Meeting, Orlando, FL, Jan 2005, 235-238.

M. Hoffert, K. Caldiera, A. K. Jain, E. F. Haites, L. D. Danney Harvey, S. D. Potter, M. E. Schlesinger, S. H. Schneider, R. G. Watts, T. M. L. Wrigley, D. J. Wuebbles, Oct. 29, 1998, "Energy implications of future stabilization of atmospheric $\mathrm{CO}_{2}$ content," Nature, v. 395 (and http://www.nrel.gov/ncpv/thin_film/pdfs/hoffert_et_al_nature2004.pdf).

K.W. Jansen, H. Volltrauer, A. Varvar, D. Jackson, B. Johnson, L. Chen, J.A. Anna Selvan, A.E. Delahoy, 2005. "Advancements in A-Si Module Manufacturing at Energy Photovoltaics, Inc.,” (Energy Photovoltaics, Inc., 276 Bakers Basin Rd., Lawrenceville NJ, 08648, USA), $20^{\text {th }}$ EUPVSC Meeting, Barcelona, Spain, June 2005.

M. Keshner and R. Arya, 2004, Study of Potential Cost Reductions Resulting from SuperLarge-Scale Manufacturing of PV Modules: Final Report, Sept. 30, 2004; NREL Report No. SR-520-36844 and http://www.nrel.gov/docs/fy05osti/36846.pdf .

K Ernst, A Belaidi and R Könenkamp, 2003, "Solar cell with extremely thin absorber on highly structured substrate," Semiconductor Science and Technology, 18, 475-479.

Nate Lewis, 2004, “A Global Energy Perspective,” Caltech, The Lewis Group, http://www.its.caltech.edu/ mmrc/nsl/energy.html .

James Mason, November 2004, Life Cycle Analysis of a Field,, Grid-Connected, MultiCrystalline PV Plant: A Case Study of Tucson Electric Power's Springerville PV Plant, Final report prepared for TEP.

NREL, 2005, "Will we have enough materials for PV to meet the climate change Terawatt Challenge?", NREL FAQ by K. Zweibel, http://www.nrel.gov/ncpv/pvmenu.cgi?site + ncpv\&idx=3\&body=faq.html

NREL, 2005a, "What is the energy payback of PV?", NREL FAQ by K. Zweibel, http://www.nrel.gov/ncpv/pvmenu.cgi?site+ncpv\&idx=3\&body=faq.html .

R.C. Powell, Research Leading to High Throughput Manufacturing of Thin-Film CdTe PV Modules, September 2004, First Solar Thin Film Photovoltaic Partnership Program Annual Report, NREL, First Solar, LLC, http://www.nrel.gov/ncpv/thin_film/docs/first_solar_tfppp_ann_rpt_sept 2004.doc.

M. Raugei, S. Bargiglie, S. Ulgiati, 2005, "Energy and Life Cycle Assessment of Thin Film CdTe PV Modules," in $20^{\text {th }}$ European PVSC Conference, Barcelona, Spain. K. Ramanathan, J. Keane, R. Noufi, 2005, "Properties of High Efficiency CIGS Thin Film Solar Cells," Proceedings of the IEEE PV Specialists Meeting, Orlando, FL, Jan 2005, 195-198.

B. A. Sanden (formerly Andersson), 2003, "Materials availability for thin film PV and the need for 'technodiversity', EUROPV 2003, Granada, Spain. 
USGS 2003 , Historical Statistics for Mineral Commodities in the United States http://minerals.usgs.gov/minerals/pubs/of01-006/index.html .

B. von Roedern, K. Zweibel, H. S. Ullal, 2005, "The Role of Polycrystalline Thin Film Technologies for Achieving Mid-Term, Market-Competitive, PV Modules," Proceedings of the IEEE PV Specialists Meeting, Orlando, FL, Jan 2005, 183-188.

R. Wieting, 2005, "CIS Thin Film Manufacturing at Shell Solar: Practical Techniques in Volume Manufacturing," Proceedings of the IEEE PV Specialists Meeting, Orlando, FL, Jan 2005, 177-182.

K. Zweibel, H. S. Ullal, B. Von Roedern, October 2004, “Finally: Thin Film PV!” in Photon International, M. Schmela (ed.), p. 48-56.

\section{Acknowledgments}

I would like to thank all those within the private sector who have contributed insights and cost inputs. Their service to clarifying the potential of thin films for meeting the TW Challenge is an important contribution as corporate citizens. I would also like to thank those who provided guidance, inputs, and challenges: especially Nate Lewis; Marty Hoffert, Tom Hansen, James Mason, Dave Mooney, Bjorn Sanden, Bob Williams, Steve Johnson, Dan Sandwich, Chip Hambro, Glen Hamer, and Dave Pearce. 


\section{Appendix 1. Calculating Levelized Energy Cost from System \$/Wp DC Costs}

Table A-1. Conversion of $\$ 1 / \mathrm{Wp}$ (DC) to $\mathrm{c} / \mathrm{kWh}$ (fixed flat plates) without $\mathrm{O \& M}$

\begin{tabular}{|l|l|l|l|}
\hline & $\begin{array}{l}\text { Average Location } \\
\text { (e.g., Kansas City) }\end{array}$ & $\begin{array}{l}\text { Below Average } \\
\text { (Maine or Seattle) }\end{array}$ & $\begin{array}{l}\text { Above Average } \\
\text { (Phoenix or } \\
\text { Albuquerque) }\end{array}$ \\
\hline $\begin{array}{l}\text { Sunlight (kWh/m }{ }^{2}- \\
\text { yr) and capacity } \\
\text { factor (= } \\
\mathbf{0 . 8} * \text { sunlight/(8760) }\end{array}$ & $\begin{array}{l}1700 \mathrm{kWh} / \mathrm{m}^{2}-\mathrm{yr} \\
15.5 \%\end{array}$ & $\begin{array}{l}1300 \mathrm{kWh} / \mathrm{m}^{2}-\mathrm{yr} \\
12 \%\end{array}$ & $\begin{array}{l}2300 \mathrm{kWh} / \mathrm{m}^{2}-\mathrm{yr} \\
21 \%\end{array}$ \\
\hline $\begin{array}{l}\text { Levelized Energy } \\
\text { Cost }(\boldsymbol{\phi} / \mathbf{k W h})\end{array}$ & $5.9 \phi / \mathrm{kWh}$ & $7.7 \phi / \mathrm{kWh}$ & $4.4 \phi / \mathrm{kWh}$ \\
\hline
\end{tabular}

Using this table, one can estimate the LEC of any system (assuming the same set of financial and other terms) by merely multiplying the system $\$ / \mathrm{Wp}$ by the proper number, above (e.g., a $\$ 5 / \mathrm{Wp}$ system would be 5 times more than the $\phi / \mathrm{kWh}$ level in Table A1) and then adding in the O\&M, which is usually very small (about $0.1 \phi / \mathrm{kWh}$ for a fixed flat plate).

The LEC values in Table 1 were calculated using the standard formula for amortization of cost over time, assuming the system is financed through a loan matched to the lifetime of the system.

$\mathrm{LEC}=(\mathrm{ICCx} 1000 \mathrm{xCRF}) /(\mathrm{CFx} 8760)+\mathrm{O} \& \mathrm{M}$, where

ICC $=$ Installed Capacity Cost (\$/Wp DC),

$\mathrm{CRF}=$ Capital Recovery Factor $=\left(i^{*}(\mathrm{i}+1)^{\wedge} \mathrm{n}\right) /\left((\mathrm{i}+1)^{\wedge} \mathrm{n}-1\right)$,

$\mathrm{CF}=\mathrm{AC}$ Capacity Factor $(0.8 *$ sunlight $/ 8760$ hours, reduced by $20 \%$ losses to go from $\mathrm{DC}$ to $\mathrm{AC})$,

O\&M $=$ Operation and Maintenance $(\$ / \mathrm{kWh})$,

$\mathrm{i}=$ interest rate,

$\mathrm{n}=$ system lifetime (i.e., how many years to amortize cost of system over).

Assumptions are: $\mathrm{O} \& \mathrm{M}=\$ 0.001 / \mathrm{kWh}, \mathrm{i}=7 \%, \mathrm{n}=30$ (no tax credits and no accelerated depreciation); for these, $\mathrm{CRF}=0.081$.

For comparison, the LEC for an Advanced Combined Cycle Plant is currently $5.6 \phi / \mathrm{kWh}$ at a capacity factor of $50 \%$ and $7.6 \phi / \mathrm{kWh}$ at a capacity factor of $25 \%$, under the following assumptions: Plant size $=400 \mathrm{MWe}$, Heat Rate $=6422 \mathrm{Btu} / \mathrm{kWh}$, Capital Cost $=\$ 599 / \mathrm{kWe}$, Fixed O\&M = \$10.34/kWyr, Variable O\&M=2.07 mil $/ \mathrm{kWh}$, Burner Tip Gas Price=\$5/MMBtu, 20 year IRR@12\%, 15 year Dept @6\%. 


\section{Appendix 2. Latest (prepublication) table of thin film module efficiencies taken from websites (August 2005)}

Table A-1. Commercial Thin Film Modules, Data Taken from Websites

(total area efficiencies)

Compiled by Bolko von Roedern; 8/2005

\begin{tabular}{|l|l|l|l|l|}
\hline $\begin{array}{l}\text { Rated } \\
\text { Module } \\
\text { Efficiency } \\
(\%)\end{array}$ & Description & $\begin{array}{l}\text { Rated } \\
\text { Output } \\
\mathbf{W p}\end{array}$ & $\begin{array}{l}\text { Estimated } \\
\text { Price } \mathbf{( \$ / W p )}\end{array}$ & $\begin{array}{l}\text { Temperature } \\
\text { coefficient* }\end{array}$ \\
\hline 11.0 & WürthSolar WS31050/80 (CIS) & 80 & Above $\$ 3 / \mathrm{Wp}$ & $-0.36 \% /{ }^{\circ} \mathrm{C}$ \\
\hline 9.4 & Shell Solar ST-40 (CIS) & 40 & Above $\$ 3 / \mathrm{Wp}$ & $-0.6 \% /{ }^{\circ} \mathrm{C}^{* *}$ \\
\hline 9.0 & First Solar FS65 (CdTe) & 65 & Below $\$ 3 / \mathrm{Wp}$ & $-0.25 \% /{ }^{\circ} \mathrm{C}$ \\
\hline 6.9 & Antec-Solar ATF50 (CdTe) & 50 & Below $\$ 3 / \mathrm{Wp}$ & $-0.18 \% /{ }^{\circ} \mathrm{C}$ \\
\hline 6.3 & $\begin{array}{l}\text { Kaneka GEA/GSA (single-j. } \\
\text { a-Si) }\end{array}$ & 60 & Below $\$ 3 / \mathrm{Wp}$ & $-0.2 \% /{ }^{\circ} \mathrm{C}$ \\
\hline 6.4 & $\begin{array}{l}\text { Mitsubishi Heavy MA100 } \\
\text { (single j. a-Si, VHF deposition) }\end{array}$ & 100 & Below $\$ 3 / \mathrm{Wp}$ & $-0.2 \% /{ }^{\circ} \mathrm{C}$ \\
\hline 6.3 & $\begin{array}{l}\text { Uni-Solar US-64 (triple-j. } \\
\text { amorphous silicon), }\end{array}$ & 64 & \$3.3/Wp & $-0.21 \% /{ }^{\circ} \mathrm{C}$ \\
\hline 5.3 & $\begin{array}{l}\text { RWE Schott ASI-F32/12 (same } \\
\text { bandgap a-Si tandem) }\end{array}$ & 32.2 & Varies & $-0.2 \% /{ }^{\circ} \mathrm{C}$ \\
\hline
\end{tabular}




\section{REPORT DOCUMENTATION PAGE}

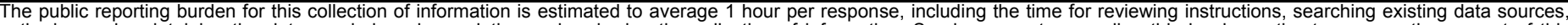

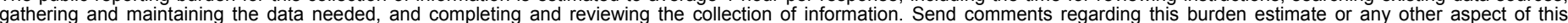

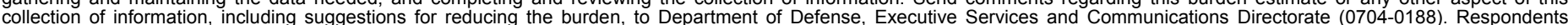

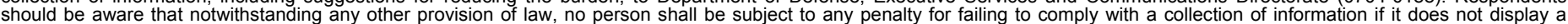

should be aware that notwithstandin

PLEASE DO NOT RETURN YOUR FORM TO THE ABOVE ORGANIZATION.

\begin{tabular}{l|l|l|l} 
1. REPORT DATE (DD-MM-YYYY) & 2. REPORT TYPE & 3. DATES COVERED (FrOm - TO)
\end{tabular}

August 2005

Technical Report

4. TITLE AND SUBTITLE

The Terawatt Challenge for Thin-Film PV

5a. CONTRACT NUMBER

DE-AC36-99-G010337

5b. GRANT NUMBER

5c. PROGRAM ELEMENT NUMBER

6. AUTHOR(S)

K. Zweibel

5d. PROJECT NUMBER

NREL/TP-520-38350

5e. TASK NUMBER

PVB55101

5f. WORK UNIT NUMBER
7. PERFORMING ORGANIZATION NAME(S) AND ADDRESS(ES)

National Renewable Energy Laboratory

1617 Cole Blvd.

Golden, CO 80401-3393

9. SPONSORING/MONITORING AGENCY NAME(S) AND ADDRESS(ES)
8. PERFORMING ORGANIZATION REPORT NUMBER

NREL/TP-520-38350
10. SPONSOR/MONITOR'S ACRONYM(S) NREL

11. SPONSORING/MONITORING AGENCY REPORT NUMBER

12. DISTRIBUTION AVAILABILITY STATEMENT

National Technical Information Service

U.S. Department of Commerce

5285 Port Royal Road

Springfield, VA 22161

13. SUPPLEMENTARY NOTES

\section{ABSTRACT (Maximum 200 Words)}

The evolution of PV into one of the world's largest industries is not going to happen without major unforeseen problems. However, this study attempts to address the obvious ones, so that we can put aside the mythology of PV (for example, that it is only 'boutique power' or that one must pave the world with it to be useful) and get on with changing the world's energy infrastructure. With the years of rapid market growth now under way in PV, the author is sure this will not be the last effort to understand the real potential and pitfalls of meeting the Challenge.

\section{SUBJECT TERMS}

PV; Terawatt challenge; thin film; manufacturer; energy payback;

\begin{tabular}{|c|c|c|}
\hline $\begin{array}{l}\text { a. REPORT } \\
\text { Unclassified }\end{array}$ & $\begin{array}{l}\text { b. ABSTRACT } \\
\text { Unclassified }\end{array}$ & $\begin{array}{l}\text { c. THIS PAGE } \\
\text { Unclassified }\end{array}$ \\
\hline
\end{tabular}

\begin{tabular}{|c|c|}
\hline $\begin{array}{l}\text { 17. LIMITATION } \\
\text { OF ABSTRACT }\end{array}$ & $\begin{array}{l}\text { 18. NUMBER } \\
\text { OF PAGES }\end{array}$ \\
\hline UL & \\
\hline
\end{tabular}

19a. NAME OF RESPONSIBLE PERSON

19b. TELEPHONE NUMBER (Include area code) 